\title{
1 \\ The Role of Intellectual Property Rights in the Development Process, with Some Lessons from Developed Countries: An Introduction ${ }^{1}$
}

evelop-

chester

\author{
Giovanni Dosi and Joseph E. Stiglitz
}

This book analyzes the impact of diverse intellectual property rights (IPR) regimes upon the development process.

The relationship between IPR and development has become a source of increasing concern over the past fifteen years, for two related reasons: (a) it has become increasingly recognized that what separates developed from developing countries is a gap in knowledge, and that inappropriately designed IPR regimes can present an important impediment to closing the knowledge gap, and therefore to development; and (b) at the same time, the Agreement on Trade-Related Intellectual property Agreements (TRIPS) ${ }^{2}$ of the Uruguay Round imposed a Western-style IPR regime on developing countries, one which many developing countries rightly worried might impede their access to knowledge, and thus their development.

So concerned have many of those in the developing countries become about the adverse effects of this intellectual property regime that they have called for a "development-oriented intellectual property regime," just as they had, at Doha, called for a development-oriented trade regime. On 4 October 2004 the General Assembly of the World Intellectual property Organization (WIPO), decided to advance an IPR agenda that was, for the first time, explicitly developmentally oriented. The adoption of the Brazilian and Argentinean proposal for a development agenda was a major step forward for several reasons. First, it recognized that intellectual property "is not an end in itself." Second, it reiterated WIPO's mission to "promote creative intellectual activity" and "the transfer of technology to developing countries." The new development agenda calls for ascertaining how different intellectual property regimes affect developing countries. This volume can be seen, in part, as providing some of the intellectual foundations for that analysis. 
Developing countries have claimed that the IPR regime that the West advocates impairs their development not only by failing to give them access to knowledge, but also by failing to protect their intellectual property-both traditional knowledge and the knowledge embedded in biodiversity. This asymmetry too has adverse effects on development, for it necessitates developing countries paying large rents to Western firms for their intellectual property, but not receiving in return rents from what the developing countries view as their intellectual property. Indeed, in some cases, developing countries would have to pay Western firms rents for what developing countries view as their own property.

The United States has, for instance, granted patents for traditional knowledge (such as traditional medicinal uses of certain plants), which developing countries argue should not be patentable. Traditionally, this type of knowledge was held by communities and made freely available. Developing countries have widely criticized the patents on neem oil, basmati rice, and the medicinal uses of turmeric. ${ }^{4}$ But the United States has not even ratified the Convention on Biological Diversity, under pressure from the pharmaceutical companies that fear it would provide (what they consider to be) "excessive" protection for the intellectual property associated with the use in their products of genetic material derived from plants or animals in, say, developing countries-even if the countries from which they had taken the plant or animal had devoted considerable resources to preserving their biodiversity. Evidently, in this line of argument, while incentives are important for the pharmaceutical companies, they are not for countries; and while companies should be rewarded for "discovery," countries should not be rewarded for protecting their biodiversity-without which the discovery would not have been possible. The one point of intellectual consistency in the position of the United States is that it seeks an IPR regime that maximizes the rents for its companies and minimizes the rents that its companies might pay to others.

Developed countries have tried to argue that "strong" IPR (in which traditional medicine can be patented, but genetic material that developing countries believe is theirs is left unprotected ${ }^{5}$ ) is in the best interests of developing countries. The papers in this book, and the discussion below, suggest such contentions are incorrect.

Indeed, the IPR regime that the United States has pushed on the world was not the one its scientists and innovators advocated. It was the IPR regime that the drug and entertainment industries advocated. One of us (Stiglitz) had the opportunity to see this first hand: ${ }^{6}$

When I served on President Clinton's Council of Econornic Advisers, we provided our assessment of the TRIPS agreement, the intellectual property provisions of the 1994 WTO Uruguay Round agreement, which sought to impose an American style intellectual property regime on developing countries. Both we and 
he West

n access

$y$-both

ity. This es develtellectual countries countries s view as

al knowaveloping nowledge countries medicinal onvention ompanies ection for of genetic s-even if d devoted n this line al comparewarded ting their possible. ited States panies and

(in which developing nterests of ion below, world was regime that itz) had the the Office of Science and Technology Policy within the White House basically opposed TRIPS, believing that it was bad for American science, global science, and the economies of the U.S. and developing countries alike. Many of America's own innovative firms are trying to change its IPR regime, which is designed not to maximize innovation but rents from those who have had the good luck receiving a patent (and the two are not the same).

Along with many of the authors of the papers in this volume, we believe that there is a need for reform in the U.S. IPR regime and that it would be wrong to impose such a flawed regime on others. (Indeed, the United States has been reforming its regime; ${ }^{7}$ there is a worry that others will be left with an IPR regime that even the United States has rejected.) As badly designed as the American IPR regime is for the United States, it is even worse suited for developing countries. But even if the American IPR regime were ideal for the United States, that does not mean that it would be ideal for others.

Among the central theses of this introduction, and the papers in this book, are the following:

(i) Intellectual property is man-made; it is a social contrivance purportedly designed to increase welfare, by supposedly enhancing innovation (though, as we shall see, it may actually have exactly the opposite effect). Moreover, the focus on intellectual property rights ignores the fact that all property rights come with restrictions; they are never unfettered (Kennedy and Stiglitz, 2013). In the case of intellectual property rights, there are restrictions associated both with abusesthey cannot (or should not) be used to unduly restrict competitionand also with public uses-compulsory licenses can and have played an important role in ensuring access to knowledge when it is deemed central for the public interest. Part of the granting of a patent is full disclosure of relevant information, so that others can build upon the knowledge. Different countries may come to different judgments about which abuses are unacceptable or which public interests are essential.

(ii) In general, the private returns to innovation with intellectual property are not well-aligned with social returns. 8

(iii) Most broadly, the link between stronger IPR and innovation is ambiguous at best.?

(iv) The impact of IPR on welfare and innovation depends on details of the IPR regime and the nature of the sector--institutional details matter. Advocates of IPR in advanced industrial countries have not only focused excessively on IPR. They have also typically argued that the better and stronger intellectual property rights are, the more innovative the economy will be. ${ }^{10} \mathrm{We}$ show, to the contrary, that there is 
considerable subtlety in the design of a good IPR regime. In the discussion below, we will explain that there are many details in the design of an intellectual property regime that affect the extent to which it promotes or impedes innovation. It is not just a question of "strong" or "weak" intellectual property rights. Rather, the design of the whole intellectual property regime, with its myriad of provisions, is what matters. ${ }^{11}$

(v) Poorly designed IPR systems may not enhance welfare, both in the short run and in the long; and such systems may well impede innovation. We will explain that the IPR regime in the United States, and which the United States has attempted to foist on developing countries, may actually be welfare reducing. Both the levels and patterns of innovation may be adversely affected. Interestingly, as we have noted, even many in the United States high-tech sectors have come to recognize this, and there have been marked changes in the IPR regime in recent years. Not all have been positive, but even the positive ones have not yet been incorporated into other countries' IPR regimes.

(vi) Intellectual property is only one way of incentivizing innovative research; it is only one part of what might be thought of as a country's innovation system, the collection of institutions that promote innovation; there has been too much emphasis on IPR, to the exclusion of other ways of stimulating innovation and learning.

(vii) An intellectual property regime that might be appropriate for one country or one sector might be inappropriate for another.

(viii) In particular, the IPR regimes of the advanced developed countries are likely to be inappropriate for many developing countries, and this is likely to be especially so in areas like bealth and agriculture. One reason that an IPR regime designed for advanced developed countries may be inappropriate for developing countries is that institutional transplants generally don't work. Indeed, one-size-fits-all policy prescriptions are rarely a good idea in any field, ${ }^{12}$ but this is one area where they may work particularly badly. Institutional structures have to be sensitive to differences in objectives and circumstances -including the broader set of institutional arrangements, which inevitably differ from country to country, shaped by circumstances and history. There are, for instance, large distributional consequences of different IPR regimes, and developing countries may not have the resources to easily offset those effects. Moreover, much innovation occurs within and is supported by non-market

inst

to 1

with

The implica property rigl jective is to property rigl this through institutions ( circumstance stances, intel innovation. appropriate $\mathrm{t}$

As we note the country's isolation. It c entire econo citizens. It $c$ States, where for drugs, th government ment-finance (though that opportunity $\mathrm{c}$ been better $\mathrm{s}$ better ways to

The discuss tally oriented

Tbe discuss general theor consequences make some $\mathrm{cr}$ The third dis innovation, lo between patel central elemer innovation sys countries eng with a brief $d i$ regimes that $\mathrm{s}$. 
egime. In the details in the the extent to a question of the design of of provisions,

e, both in the well impede United States, on developing he levels and terestingly, as $\mathrm{h}$ sectors have hanges in the but even the her countries'

ng innovative as a country's comote innovte exclusion of

priate for one her.

ped countries atries, and this riculture. One veloped counis that institune-size-fits-all eld, ${ }^{12}$ but this . Institutional objectives and ional arrangetry, shaped by distributionping countries cts. Moreover, y non-market institutions. The excessive focus on IPR - a market-based approach to promoting innovation-ignores the effects on and interactions with these other parts of countries' innovation systems.

The implications of this analysis can be summarized briefly: Intellectual property rights-like other institutions-are social constructions whose objective is to promote the well-being of society. In the case of intellectual property rights, well-designed intellectual property regimes attempt to do this through the expansion and deepening of its knowledge base. But all institutions (including intellectual property rights) need to be adapted to the circumstances, history, and objectives of each country. In many circumstances, intellectual property rights may not be the best way of promoting innovation. Developing countries need to design their own IPR regimes, appropriate to their economies and circumstances.

As we noted, a country's IPR system does not exist in isolation; it is part of the country's innovation system. And the innovation system does not exist in isolation. It can, for instance, affect the competitiveness and efficiency of the entire economy, the extent of inequality in society, and the health of its citizens. It can even have large budgetary consequences, as in the United States, where the government pays pharmaceutical companies large amounts for drugs, the production costs of which are but a fraction of what the government pays-in some cases, even for drugs largely based on government-financed research. The United States may be able to afford such largesse (though that is increasingly being questioned). For developing countries, the opportunity cost of these expenditures is enormous-the money could have been better spent promoting education or innovation-and there are even better ways to spend the government's health budget.

The discussions in this book will hopefully point the way to a developmentally oriented intellectual property regime.

The discussion of this chapter is divided into six parts. The first presents the general theory of innovation, in the context of which we can evaluate the consequences of stronger IPR. The second employs this general theory to make some critical observations of the role of IPR in promoting innovation. The third discusses some of the evidence on the role of IPR in promoting innovation, looking particularly at the empirical evidence on the relationship between patents, appropriability, and innovation. The fourth presents the central elements of what we may call the "portfolio approach to an effective innovation system." The fifth focuses on the special problems of developing countries engaged in late industrialization and catching-up. We conclude with a brief discussion of some recent developments in intellectual property regimes that shed light on the issues raised here. 


\section{THE GENERAL THEORY OF INNOVATION AND THE ROLE OF IPR}

That profit-motivated innovators are fundamental drivers of the "unbound Prometheus" of modern capitalism (Landes, 1969) has been well appreciated since Smith, Marx, and later, Schumpeter. And the last half a century has also seen in-depth analyses of determinants of the pace of technological progress and entrepreneurs' and business firms' propensity to innovate (for a thorough survey, see Dosi and Nelson, 2010).

There are many sources of innovation. Some come from outside the industry such as the advances in applied science, generally stemming from public laboratories and universities. However, at least equally important in a modern economy are the activities of search, including of course research and development expenditures, undertaken by business firms-explicit investments in developing new products that consumers and firms value, or new processes that reduce the costs of production. But if firms are to make these investments, they have to reap a return. If they appropriate for themselves less than the full social return to their innovation (and if firms were able ex ante to make accurate predictions on actual costs and returns), then there might be private underinvestment in innovation. The intent of the patent (IPR) system is to enable individuals and firms to garner for themselves a larger fraction of the social returns resulting from their innovative activity. ${ }^{13}$

But there are circumstances in which, especially under a strong patent system, the returns they reap can actually be in excess of the marginal social product. The marginal social product is related to the fact that the innovation is available earlier than it otherwise would have been. A firm's contribution can be negligible, and yet its rewards large. Moreover, an innovation may garner for a firm high profits in an imperfectly competitive industry, by seizing a fraction of its rivals' profits with a me-too innovation. These are not just theoretical niceties: me-too innovations abound in the pharmaceutical indus try. So do attempts to appropriate advances in scientific knowledge: a good example is the medical diagnostic company Myriad, which rushed to beat the human genome project in identifying the BRCA genes related to breast cancer, so that it could get patents from which it could extract large rents from any woman wanting to find out whether she had a high risk of getting cancer. In that case, the net social return was negative, for the patents allowed the company to charge a high fee, well beyond the ability of anyone who is poor without insurance to pay. After years of legal wrangling, the Supreme Court finally struck down Myriad's patents on human genes in June 2013. However, this did not happen before many women were forced to make agonizing life-or-death decisions about treatment and preventative measures, with incomplet because th

Sometis investmen a patent produced.

Later in system ma

Any analy how is the the case of and there case of th presumpti rights," is

The fun that it is a knowledge inefficient from the $\mathrm{kI}$ on governn and financi markets to competitive sufficient to tion of sucl Marx to Sch was necessa

Granted and what a research, th returns. Bu cient utiliza have referre "tragedy of inability, wi commons, 1 commons is Those that 
incomplete information, either because they could not afford the tests or because the patents prevented second opinions. ${ }^{14}$

Sometimes knowledge is produced as a by-product of production and investment. In that case, there may be little need to provide incentives; ${ }^{15}$ but a patent can reduce access by others to the benefits of the knowledge so produced. Again, in that case, patents can have a negative social impact.

Later in this introduction, we will explain other ways in which the patent system may impede innovation.

\section{Knowledge as a (quasi-) public good}

Any analysis of innovation and the patent system begins with the question, how is the production of knowledge different from that of ordinary goods? In the case of ordinary goods, there is a presumption that markets are efficient, and there is little controversy about the definition of "property rights." In the case of the production of knowledge, there is, as we have just seen, no presumption that private production, with or without "intellectual property rights," is efficient.

The fundamental problem with knowledge, it has come to be recognized, is that it is a quasi-public good (it is often hard to exclude others from the knowledge a person or corporation acquired, ${ }^{16}$ and even if it were possible, it is inefficient to do so, since one person's access to knowledge does not detract from the knowledge of others) ${ }^{17}$ But unlike other public goods where we rely on government provision, we turn to the private sector for both production and financing of much innovation. The challenge has been how to get private markets to provide the desirable level and form of such a public good. Efficient competitive markets might be unable to generate a stream of quasi-rents sufficient to motivate profit-seeking firms to invest resources in the production of such goods (Arrow 1962a). A long line of economists (from Smith to Marx to Schumpeter (1943)) argued that in order to provide such incentives, it was necessary to depart from pure competition. ${ }^{18}$

Granted that, however, what is empirically the extent of such a departure, and what are the consequences? Clearly, if there is to be private provision of research, those engaging in research have to be able to appropriate some returns. But any such appropriation necessitates an impediment to the efficient utilization of knowledge. Heller (1998) and Heller and Eisenberg (1998) have referred to the underutilization of knowledge as a result of patents as the "tragedy of the anti-commons." The tragedy of the commons was the (alleged) inability, without property rights, to exclude individuals from the use of the commons, leading to over-utilization, e.g. overgrazing. The tragedy of the anticommons is that knowledge, for which utilization is non-rivalrous, is restricted. Those that argued that property rights were essential for preventing the 
tragedy of the commons were wrong; regulatory mechanisms can be just as effective, without the adverse distributive consequences (see e.g. Ostrom, Gardner, and Walker, 1994.) So too we argue here that property rights are not always the best solution to the appropriability problem.

This raises the question, what is the "desirable" degree of appropriability? And through which mechanisms?

Appropriability occurs through patent and copyright protection, but there are alternative, perhaps more important, mechanisms. Because of lead times and the costs and time required for duplication and learning, and because of the availability of specific manufacturing facilities and sales networks, the first innovator can typically appropriate some returns to his innovation, even without IPR; secrecy and the fact that much relevant knowledge is "tacit" can enhance the ability of firms to appropriate returns on their investments in knowledge (these mechanisms of appropriation are discussed at length in Dosi and Nelson, 2010).

The choice of the appropriability mechanism may be largely dictated by the nature of technology, with some industries relying on trade secrets, lead times, and the sheer complexity of products, rather than IPR. ${ }^{19}$ The diversity mechanisms through which firms benefit from innovation, however, has been lost in a good deal of contemporary literature on innovation, in which it seems to be assumed that the only way by which appropriability occurs is tbrough IPR.

In fact, there seems to be no compelling evidence of a positive relation, above some threshold, between appropriability in general-and even more so, the tightening of IPR regimes-on the one hand, and the rates of innovation, on the other. The discussion below will explain why this empirical result should not come as a surprise.

While the evidence that IPR in general promotes innovation is far from convincing, there is good evidence that there may be adverse effects, especially with poorly designed "tight" IPR regimes: access to life-saving medicines may be restricted and so too access to knowledge that is necessary for successful development, and even for follow-on innovation. As governments have to spend more money to purchase the drugs they need, because of reduced availability of low-cost generic medicines, other expenditures-from those necessary to promote growth to those devoted to alleviating poverty-are reduced. Conversely, there may be perverse links between IPR protection and income distribution. Moreover, even if an IPR regime promoted growth in, say, some sector in some industrial country, it does not mean it will do so in other sectors and/or in other countries.

\section{Some failures of the "market failure" arguments}

We begin by considering the main arguments supporting IPR, then turn to why the traditional analyses fail to provide an adequate description of the 


\section{Intellectual Property Rights in the Development Process}

be just as

Ostrom, rights are

opriability?

1, but there lead times because of ks, the first ation, even ge is "tacit" estments in 1gth in Dosi

tated by the , lead times, ersity mechas been lost a it seems to hrough IPR. ive relation, ven more so, innovation, pirical result 1 is far from cts, especially edicines may or successful ients have to e of reduced -from those poverty-are R protection noted growth it will do so in rription of the innovation process - and thereby why they fail to provide a persuasive analysis of the role of IPR in supporting the innovation process.

The economic foundations of the theory supporting IPR rest upon a standard market failure argument: Markets perfectly fulfil their allocative role only in the absence of externalities. Without full appropriability, there will be, as we have noted, positive externalities to research, and this in turn leads to underinvestment and underproduction of knowledge. There is a (partial) market-based solution: even though knowledge is "non-rivalrous" one can attempt to make it partially excludable, e.g. through patents. This will mean that more of the benefits of the knowledge will be appropriated by those who invest in knowledge.

But it also means that, because of the artificial scarcity, the knowledge that has been produced is not being used efficiently. This tension between purported incentives for the creation of knowledge and its efficient utilization is a theme that plays out throughout most analyses of the appropriate design of IPR.

As this volume illustrates, matters are even worse: granting exclusivity to the use of knowledge is tantamount to granting a (limited) monopoly; but sometimes the monopoly power thus granted is leveraged further to create market power in segments of the economy. Sometimes, at great expense, governments have acted to curb some of the abuses of this market power (as in the case of Microsoft), but even after taking actions to limit anticompetitive practices, monopoly power persists. Not only does this result in a distorted, less efficient economy, but, as we shall comment later, even innovation may be hurt-ironic, since the putative purpose of IPR is to promote innovation.

The core of the design of a good IPR regime then becomes (a) balancing out the detrimental effect of the deadweight loss implied by a legally enforced monopoly, on the one hand, and the beneficial effect of investments in R\&D and more generally in knowledge generation, on the other; and (b) detailed provisions which limit the adverse static costs and maximize the dynamic benefits. Of course, if IPR actually impedes innovation, then there is no tradeoff: the economy loses in the short run and the long. Unfortunately, it appears that too often the dynamic consequences are at best mixed-some forms of innovation are helped, others are hurt. Well-designed IPR regimes are those that minimize both the short-run allocative costs, the long-run dynamic impediments to innovation, and the incentives for rent-seeking innovations which have minimal positive, or even negative, effects on welfare, while enhancing the positive incentives for welfare-enhancing innovations.

But IPR regimes can only go so far: IPR more broadly needs to be seen as part of a country's innovation system (Stiglitz, 2012; Freeman, 1987; Lundvall, 2010; Nelson, 1993, 2004a, 2004b, 2006); and the design of a good innovation system consists of looking for ways of enhancing simultaneously dynamic and 
static efficiency-a high level of knowledge generation combined with a system of efficient utilization of knowledge.

\section{Patents and monopolization}

Advocates of strong IPR discount the adverse effects of monopolization, thinking that monopolies would be short-lived, since the force of "Schumpeterian competition" would lead one monopolist to be replaced by another. Schumpeter and quite a few after him thought there would be competition for the market, rather than competition in the market, and that competition for the market would be sufficiently keen that consumers would reap large benefits. Schumpeter and many of his followers touted the advantages that arise from the greater level of innovation, arguing that they more than outweighed the distortions associated with monopoly.

But research over the past three decades has shown that all of these contentions are questionable. Monopolists have the ability and incentives to deter others from entering, so that monopolies can persist (see, e.g. Dasgupta and Stiglitz, 1980 and Gilbert and Newbery, 1982).

While Arrow (1962a) suggested that monopolies have far weaker incentives to innovate (compared to the social optimum), Dasgupta and Stiglitz (1980), Stiglitz (1988), and Fudenberg et al. (1983) have shown that matters are far worse than Arrow thought: a monopolist can maintain his position simply by getting a little bit ahead of his rivals, enough ahead that the rivals know that should they enter the fray, he will outcompete them. Worse still, recent years have seen monopolists using their monopoly power to squelch innovators who represent a threat to their dominant position; and the knowledge that they have the incentive, resources, and tools to do so provides a disincentive to innovation. Microsoft has provided the example par excellence of this behaviour. Integrating Internet Explorer into its operating system meant providing the browser at an essentially zero price, making it impossible for the market innovator in browsers, Netscape, to compete. Even though Microsoft was charged with anticompetitive practices in Europe, America, and Asia, and agreed to discontinue these practices, Netscape never recovered.

\section{Patents, access to knowledge, and innovation}

There are other reasons that IPR may be bad for innovation: one of the most important inputs into research is knowledge, and IPR reduces access to knowledge. ${ }^{20}$

Matters might not be so bad in a world with perfect information, in which the owner of the patent could act as a perfectly discriminating monopolist, charging each potential user a price which extracts the maximum rents without adversely affecting innovation. But this is not the world we live in, 
olization, schumpeanother. etition for etition for eap large tages that nore than

1 of these centives to Dasgupta

incentives litz (1980), ters are far simply by know that ecent years vators who re that they ncentive to this behavt providing the market crosoft was d Asia, and

of the most es access to

on, in which monopolist, ximum rents Id we live in,

and restrictions in access to knowledge do impede follow-on innovation. More rents to earlier innovators result in less to follow-on innovators, thus reducing their incentives to innovate.

Who has access to information and knowledge today may affect who can engage in research. Reduced access to knowledge can, as we noted, lead to reduced possibilities to invest in research and to reduced innovation. The U.S. patent system recognized this, requiring wide disclosure as a quid pro quo for granting a patent. But the disclosure requirements may not suffice to offset the adverse effects from the "enclosure of the commons." And worse, some who are the most ardent defenders of patent rights are fighting against such disclosures, and in practice, disclosure has been far from complete. ${ }^{21}$

\section{Patent thicket}

Matters have become even worse with the development of what is called the patent thicket, an overlay of intellectual property claims that makes progress difficult, at best. ${ }^{22}$ With thousands of patents being issued every year, in some areas (including many high-tech ones) it is hard to avoid trespassing on someone else's patent, and expensive and time consuming to engage in the research (reviewing patents that have been granted) that might avoid this. Modern complex products involve a myriad of components, many of which may be essential to the success of the product; and even if not essential, it may be very expensive to innovate around the patent. ${ }^{23}$

Such a patent thicket slowed the development of the airplane in the years before World War I, and it was only strong government action to override these claims by the creation of a patent pool that allowed the development of the airplane that was so central to that war (see Stiglitz, 2008; Bradshaw, 1992).

More recently, a whole industry has developed-firms that buy up patents, waiting until someone successfully produces a product that might have infringed on their patent, to sue, "holding them up", in effect, for ransom. ${ }^{24}$ To the extent that they can get more for themselves, there is less left over for the "real innovators."

The consequences of such holdups are particularly important in those industries where successful innovation requires putting together various pieces of distributed knowledge. But even without holdups, the IP system may impede innovation. The IP regime gives too many subjects the right to exclude others from using fragmented and overlapping pieces of knowledge, with the result that no one can make effective use of them (Heller and Eisenberg, 1998 and Heller, 1998). One by-product of the recent surge in patenting is that, in several domains, knowledge has been so finely subdivided into separate but complementary property claims that the cost of reassembling constituent parts/properties in order to engage in further research imposes a 
heavy burden on technological advance. This means that a large number of costly negotiations might be needed in order to secure critical licenses, discouraging the pursuit of certain classes of research projects. Not surprisingly, at the beginning of this century, Barton (2000) noted that "the number of intellectual property lawyers is growing faster than the amount of research." Since then, matters have become worse. In these circumstances, the proliferation of patents may well turn out to have the effect of discouraging innovation.

\section{Other distortions in the allocation of R\&D}

Holdup patents are but one example of socially unproductive "innovation" or innovations where social returns are markedly lower than private returns. The Myriad patent race, described earlier, provides another. But there are still others, including me-too patents-in which an innovator tries to grab part of the rents of existing patent holders; and innovation designed to extend the life of the patent, or more generally, to enhance the patent holder's monopoly returns. Some of the research (in some fields, perhaps much) is directed at getting around an existing patent, i.e. to avoid unreasonable charges for the use of a patent. ${ }^{25}$ Much of the patenting is defensive-to protect oneself against a claim of someone else. Huge amounts are spent on patent lawyers. ${ }^{26}$

Thus, while the advocates of a strong patent system champion its ability to increase the allocation of resources into innovation, critics (rightly, in our view) point out the distortionary effects, both in the short run and the long, with the result that not only may patents interfere with the efficient use of information today, but a poorly designed patent system may not even lead to a faster pace of innovation. Thus, even the classic distinction between "static" and "dynamic" efficiency may be misplaced.

More generally, rules affecting access to knowledge affect the patterns of technological evolution in directions which are, in general, far from optimal. Later in this introduction, we shall discuss how reforms in the patent system can mitigate some of the adverse effects of currently dominant IPR regimes.

\section{The multiple drivers of the innovation process}

Much of the early theoretical literature on the design of IPR was overly simplistic. It failed to take into account key aspects of the production of knowledge, the variety of ways by which the returns to innovation are appropriated, and the many problematic aspects of the IPR regimes. As we have previously commented, for instance, the most important input into the production of knowledge is knowledge itself, and any product in today's complex economy is based on a large number of separate and complementary

innovatio spective works in to identif are "joint

Part of much lik and comr easy to $\mathrm{e}$ others. In we defin ideas, an

Moreo be viewe governm fact there may in $f$ priate wi role than being the

Indeed productic ledge, wh chemical are the pr some per they are a could be some jur cannot. $^{30}$

More g a lot of knowledg organizat are stron (More in

The st private $\mathrm{p}$ interactio and that $\mathrm{c}$ institutes, rests on a Moreover 
Imber of uses, disorisingly, imber of esearch." proliferouraging

vation" or urns. The e are still ab part of nd the life monopoly directed at ges for the ect oneself lawyers. ${ }^{26}$ ss ability to tly, in our d the long, ient use of en lead to a een "static"

patterns of m optimal. tent system $\mathrm{R}$ regimes.

was overly roduction of in are approAs we have put into the ct in today's mplementary

innovations. ${ }^{27}$ This means that innovation cannot be viewed from the perspective of a one-off event. Each innovation builds on prior innovations, and works in conjunction with other innovations. It is difficult, if not impossible, to identify the productivity of one innovation in isolation from others (they are "joint" inputs). ${ }^{28}$

Part of the deficiencies in the standard theory arise from treating knowledge much like any other form of capital and property, ignoring the many subtleties and complexities. For instance, while the boundaries of real estate property are easy to establish, those of intellectual property are not. Each idea builds on others. Intellectual property was intended to encourage new ideas, but how do we define "novelty"? What ideas are the obvious consequence of previous ideas, and therefore should not be patentable?

Moreover, as we already mentioned, while many aspects of knowledge can be viewed as a "public good," for which exclusion exists only as a result of government actions through the enforcement of intellectual property rights, in fact there are many non-public aspects of knowledge-tacit knowledge that may in fact be hard to transfer, and the returns to which are easy to appropriate without IPR. In some sectors, trade secrets play a far more important role than IPR, and in most sectors, they and other returns associated with being the first entrant into a market play a major role.

Indeed, there are marked differences in the nature of "knowledge" and its production in different industries. In some cases, it is primarily tacit knowledge, which arises as a by-product of production and investment. ${ }^{29}$ In the chemical industry, identifying compounds and their effects is critical, but so are the processes by which the chemicals are synthesized. In some countries, in some periods, naturally existing compounds could not be patented-after all, they are a fact of nature, not a creation of man. Only the production processes could be patented. Analogous debates are now playing out in biotechnology: some jurisdictions have ruled that genes can be patented, others that they cannot. ${ }^{30}$

More generally, to transform information into "useful knowledge" requires a lot of search and development activities, partially based on pre-existing knowledge, processes which are to a large extent tacit and embedded in organizations. Such processes through which new knowledge is generated are strongly dependent on the specificities of each technological paradigm (More in Dosi, 1982, and Dosi and Nelson, 2010).

The standard theory suffers from another deficiency. It focuses on the private production of knowledge, not taking into account the important interactions between the production of knowledge by profit-seeking firms and that of other actors in the economy (governments, not-for-profit research institutes, universities). But private production of applied knowledge typically rests on a foundation of basic research provided by these other institutions. Moreover, the level and direction of research is affected by a whole variety of 
motivations and instruments, besides that of property rights stressed in the IPR literature. Viewing markets as embedded in and depending upon a whole ensemble of non-market institutions allows us to appreciate the fact that technological innovation is highly dependent on a variety of complementary institutions (e.g. public agencies, public policies, universities, professional communities and, of course, corporate organizations with their rich inner structure) which can hardly be called "markets" and, at best, are governed and regulated by pure market incentives only to a limited extent. ${ }^{31}$ This institutional embeddedness of innovative activities makes it very unlikely that a "market failure" approach such as the one we sketched above could provide a fully satisfactory account of the relationship between appropriability and propensity to innovate.

In short, one needs to see IPR as part of a country's innovation system, in which there are many institutions involved in the innovation process and in which there are a variety of mechanisms by which research is financed and funded and by which those engaging in research can be motivated and appropriate returns. Indeed, in some of these institutional settings (universities, for example) motivations are unrelated to standard concerns about appropriability, and enhanced appropriability has almost surely unambiguously adverse effects on innovation. ${ }^{32}$ This reinforces the earlier conclusion that there may not only be adverse static consequences from stronger IPR but adverse dynamic effects.

Both static and dynamic efficiency are affected by this broader range of instruments; and it is accordingly wrong to focus simply on market-based "tools," and among the potential market based instruments, to focus just on intellectual property rights. (See section III on alternative ways to promote innovation.)

While IPR is part-but only a part-of a country's innovation system, data presented below shows that intellectual property rights play a different role in different industries. In some industries, where follow-on (sequential) innovations are important and/or where successful projects require large numbers of complementary "ideas" and components IPR (and especially poorly designed IPR regimes) can have an especially adverse effect on innovation.

\section{SOME THEORETICAL AND INSTITUTIONAL ASPECTS OF IPR AND INNOVATION}

What we have said so far should have made clear that the conventional wisdom, that the stronger the intellectual property regime, the better-the higher the level of innovation-is wrong. In fact, there has long been doubt about the role IPR on innova "reforms" in $t$

Scepticism ab century ago, a "If we did not our present kn ing one. But s irresponsible, it" (1958: 80). that IPR is $\mathrm{n}$ institutional $r$ efficiently.

It is wortb costs of IPR, by special int remarked ear could not be through which though, mucb patentable. Th would exceed corporate inte especially in $\mathrm{t}$ science and in

The same cri current IPR re systems could have indeed b States in recen discussion of breadth of the granted, and $t$ all of tbe chan 
ssed in the

on a whole e fact that plementary rofessional rich inner verned and his institukely that a ald provide iability and

isystem, in cess and in nanced and tivated and gs (univercerns about unambigu conclusion ger IPR but

er range of arket-based cus just on to promote

ystem, data ifferent role (sequential) equire large d especially e effect on

\section{NAL}

onventional better-the been doubt

about the role of IPR in promoting innovation. To some extent, the effect of IPR on innovation depends on the design of the IPR regime. And some of the "reforms" in the IPR regime in recent years may have made matters worse.

\section{Historical scepticism about the role of patents}

Scepticism about the role of intellectual property rights is not new. A half century ago, as Fritz Machlup, whose research focused on knowledge, put it: "If we did not have a patent system, it would be irresponsible, on the basis of our present knowledge of its economic consequences, to recommend instituting one. But since we have had a patent system for a long time, it would be irresponsible, on the basis of our present knowledge, to recommend abolishing it" (1958: 80). Similar doubts are expressed in David $(1993,2002)$ who argues that IPR is not necessary for new technologies and suggests that different institutional mechanisms more similar to open science might work more efficiently.

It is worth noting that as different countries have debated the benefits and costs of IPR, over time, there have been marked changes-largely influenced by special interests, but also sometimes influenced by public policy. We remarked earlier that at some times, in some countries, chemical entities could not be patented, and patents were only granted for the processes through which the entities could be synthesized. Through all of these changes, though, much of basic research-such as mathematical concepts-were not patentable. There is a broad consensus that the costs of extending patents would exceed the benefits. The worry, however, is that, under the influence of corporate interests, the boundaries of what is patentable have been extended, especially in the United States, in ways that are adverse to the advances of science and innovation.

\section{Details matter: the challenge of designing a pro-innovation IPR system}

The same criticism can be levelled against many other provisions of the current IPR regime. While some of the observed problems with current patent systems could be obviated with a better designed system, some of them may have indeed been made worse with changes in the patent system in the United States in recent years. Details matter. For instance, while there has been much discussion of the length of the patent, equally important are questions of the breadth of the patent, the standards of novelty under which a patent can be granted, and the processes by which patents can be granted (or opposed). (Not all of the changes have been bad. Later, we will note at least one instance where 
a Court decision has reduced the scope for enforcement actions for holdup patents, which can be adverse for innovation.)

Because the boundaries of knowledge and thus also of intellectual property are fuzzy, excessively broad patent protection can be especially adverse to innovation. ${ }^{33}$ Ford had to challenge a broad patent that had been granted on self-propelled vehicles to produce his low cost "people's" car. A broad patent in genetically modified organisms (the "OncoMouse") has suppressed research and innovation in the field of cancer (see Murray et al., 2011). Patents can easily embrace existing knowledge, rewarding the patent holder well beyond his contribution. But in "fencing in the commons" access of others to incumbent knowledge and the returns that others will reap from their true contributions are reduced, again diminishing future innovation (see Boyle, 2003).

The asymmetries in getting and challenging patents worsen the problem: getting a patent privatizes what might have been public knowledge. Successfully challenging a patent converts what would have been a private good into the public domain. It is providing a public good, and, as in the case of other public goods, there will be an underprovision. That is why it is important to lower the costs of challenging the issuance of patents. European intellectual property framework is, in this respect, somewhat better than that of the United States (see Henry and Stiglitz, 2010).

These problems become more severe the lower the standard of "novelty" that is imposed in granting a patent. Several U.S. patents have been rightly criticized: Amazon's "one click" for buying online, or Apple's claim on rectangular smartphones and tablets with rounded corners are good cases to the point.

\section{Making things worse: the expansion of the IPR domain to scientific exploration and public-funded search ${ }^{34}$}

The last thirty years not only witnessed a tightening of the IPR regime in most developed countries, but brought about also (a) a significant shrinkage of the legal domains of the commons of open source; (b) a related (but not fully overlapping) extension of the domain of matters considered patentable; and (c) a significant extension of the depth and breadth of patents themselves.

The first regime change, in shorthand, goes under the heading of the BayhDole (BD) Act, encouraging American universities to patent results obtained with public funding and sell them under exclusive terms to private profitmaking actors. The issue is discussed at much greater detail by So et al. in Chapter 6 of this volume.

Bayh-Dole was a fundamental change in the premises underlying research universities, which were based on an ethos of free disclosure, and in which 


\section{$\mathrm{R}$} search $^{34}$

curiosity and the quest for knowledge drove research. Peer recognition, not monetary rewards, provided any additional incentives if required. ${ }^{35}$

Of course, the commodification of scientific inquiry stemming from BayhDole has little to do with the incentives for research provided to the scientists actually doing the research. Their research is financed ex ante by taxpayers, universities, and research institutions. ${ }^{36}$ The purported aim is an easier commercialization of its results. As we discuss below and in Chapter 6, there is little evidence of the latter, but a growing evidence on the distortion in the directions of scientific search linked with deep transformations in the institutional mission of research universities.

Of particular concern, as David (2004a and 2004b) convincingly argues, "open science" is a relatively fragile institutional arrangement. The Bayh-Dole "philosophy" may turn out to be a serious blow to open science. And because of "path dependence," once open science is undermined, it may be hard to restore. Indeed, as Chan, Sulston, and Harris argue (Chapter 5 in this volume) the domain of open science is consistent with ethical motivations supporting the value of knowledge and discovery per se, which commodification excludes. They argue that if there are rights to intellectual property, they have to compete with other (higher) rights of an ethical and moral kind. (These issues become especially relevant when IPR encroaches on access to medicines and to knowledge relevant to global warming-where overzealous enforcement of IPR can adversely affect the right to life, or even the survival of the planet.)

There have been other extensions of the domain of patentability that may have adversely affected innovation: the patentability of research tools and with that also the downstream restriction on research and on the ability of multiple researchers to draw upon each other's knowledge, building on common platforms and investments (Maskus, 1997).

This is particularly the case with patents on inventions concerning fundamental pieces of knowledge. Good examples are patents on genes or the Leder and Stewart patent on a genetically engineered mouse that develops cancer. To the extent that such techniques and knowledge are critical for further research that proceeds cumulatively on the basis of the original invention, the attribution of broad property rights might severely hamper further developments. Even more so if the patent protects not only the product the inventors have achieved (the "OncoMouse") but all the class of products that could be produced through that principle ("all transgenic non-human mammals") or all the possible uses of a patented invention (say, a gene sequence), even though they are not named in the application. In this respect, Murray et al. (2011) offers a striking illustration of how "opening up upstream" research paths can yield more search and more diverse explorations of "downstream" research paths.

Historical examples, such as those discussed by Merges and Nelson (1994) of the Selden patent of a four-wheel self-propelled vehicle (the automobile) 
and the Wright brothers' patent on an efficient stabilizing and steering system for flying machines illustrate how the IPR regime probably considerably retarded the subsequent development of automobiles and aircrafts. Earlier, at the beginning of the Industrial Revolution, the breadth of Watt's patent hindered innovation in high pressure steam engines (Nuvolari, 2004). The current debate on property rights in biotechnology suggests similar problems, where granting very broad claims on patents may have a detrimental effect on the rate of innovation, insofar as they preclude the exploration of alternative applications of the patented invention.

\section{EMPIRICAL EVIDENCE}

The ambiguous relation between appropriability (and even more so, IPR forms of appropriability) and rates of innovation puts the burden of proof upon the actual empirical record.

Indeed, the past two decades have witnessed the broadening of the patenting domain, including into areas that previously could not be so protected. This has been associated with an unprecedented increase in patenting rates. Between 1988 and 2000, patent applications from U.S. corporations more than doubled-a rate of increase of 6 per cent-well beyond the pace of innovation itself.

The relation between patenting and innovation-especially significant improvements, innovations that significantly lower, say, costs of production or providing valued services at a higher cost-has been subject to extensive controversy (for discussion, see Hu and Jaffe in Chapter 3 of this volume; Kortum and Lerner (1998); Hall (2005); Lerner (2002); Jaffe and Lerner (2004); and Jaffe (2000)).

\section{Causal links}

Even if there is a relationship between innovation and the explosion of patents, the direction of causality is not clear. One hypothesis claims that the increase of patents has been largely the consequence of the acceleration of the rates of innovation, which would have taken place even with weaker protection. This acceleration in innovation may, for instance, reflect a general increase in "technological opportunities" related, in particular, to the emergence of new technological paradigms such as those concerning information technologies and biotechnologies. (The latter is a field in which patents are a more important way to appropriability than in others. As search in the future shifts to other areas, this may no longer be true.) 
g system siderably

s. Earlier, 'ts patent 004). The problems, effect on lternative

e so, IPR n of proof

the patentprotected. ting rates. more than innovation significant production o extensive is volume; and Lerner

n of patents, the increase the rates of tection. This increase in ence of new technologies are a more future shifts

The contrary hypothesis, suggested by tight IPR supporters, in our view without much evidence to back it, is that the changes in IPR regime are a primary "cause" of increased innovation rates. Conversely, those that doubt that the increase in patenting has caused an increase in innovation sometimes go further, suggesting that changes both in the legal and institutional framework, and in firms' strategies may have led to more patenting, with little relation to the underlying innovative activities.

While it is difficult to come to sharp conclusions in the absence of counterfactual experiments, some circumstantial evidence does lend some support to the latter hypothesis.

\section{Explaining the growth of patents}

Certainly part of the growth in the number of patents is simply due to the expansion of the patentability domain to new types of objects such as software, research tools, business methods, genes and artificially engineered organisms (see also Tirole, 2002, on the European case). Moreover, new actors have entered the patenting game, most notably universities and public agencies (see for example Mowery, Nelson, Sampat, and Ziedonis, 2001).

Finally, corporate strategies vis-à-vis the legal claims of IPR also appear to have significantly changed. Patents have acquired importance among the nonphysical assets of firms as a means to signal the enterprise's value to potential investors, even well before the patented knowledge has been embodied in any marketable good. In this respect, the most relevant institutional change is to be found in the so called "Alternative 2" under the Nasdaq regulation (1984). This allowed "market entry and listing of firms operating at a deficit on the condition that they had considerable 'intangible' capital ... composed of IPR" (Coriat and Orsi 2006: 170). ${ }^{37}$

At the same time, patents seems to have acquired a strategic value, quite independently from any embodiment in profitable goods. Even in those industries in which they were not considered as an important mechanism for appropriating the benefits from innovation: extensive portfolios of legal rights are considered means for entry deterrence (Hall and Ziedonis, 2001), and for infringement and counter-infringement suits against rivals. Texas Instruments, for instance, is estimated to have gained almost $\$ 1$ billion a year from patent licenses and settlements resulting from its aggressive enforcement policy (Lerner 2010:35). It is interesting to note that this practice has generated a new commercial strategy called "defensive publishing." According to this practice, firms who find it too expensive to build an extensive portfolio of patents tend to openly describe an invention in order to place it in the "prior art" domain, thus preserving the option to employ that invention free from the interference of anyone who might eventually patent the same idea. 
The increased role that patent litigation is playing has, in turn, lead to increased patenting: patenting is designed both to build fences (not just to extend the effective life of the patent, but to deter others from entering into the fray, lest they encroach on one of the myriad of patents), and to increase one's arsenal in response to a patent infringement suit, enhancing the likelihood of a counter-suit. While such patent fences may possibly raise the private rate of return to patenting itself (Jaffe 2000), they may do so without increasing the underlying rate of innovation-and they could even have an adverse effect.

Kortum and Lerner (1998) present a careful account of different explanations of recent massive increases in patenting rates, comparing different interpretations. They look carefully at two changes in the institutional structure that may account for increased patenting. First, according to the "friendly court hypothesis," the balance between costs related to the patenting process (in terms e.g. of loss of secrecy) and the value of the protection that a patent affords to the innovator had been altered by an increase in the probability of successful application granted by the establishment in the United States of the Court of Appeals for the Federal Circuit (CAFC) specialized in patent casesregarded by most observers as a strongly pro-patent institution (cf. Merges, 1996).

Second, the "capture" hypothesis (that the patent system has been captured by large corporate interests) tries to explain the surge of U.S. patent applications tracking it back to changes in the patent regime. Business firms in general and in particular larger corporations (whose propensity to patent has traditionally been higher than average) succeeded in inducing the U.S. government to change patent policy in their favor by adopting a stronger patent regime.

\section{Patents and innovation}

What we really care about, of course, is not whether there are few or more patents, but whether the patents are associated with more innovations, and in particular, whether there are more welfare-enhancing innovations-not metoo innovations, and not innovations that serve to block others from engaging in innovation.

Lerner (2002) presents evidence that if rates of innovation have increased in recent years, the increases were not the result of the change in the IPR regime and the associated increase in patents that it caused. Rather the growth in (real) R\&D spending predates the strengthening of the IP regime.

The apparent lack of effects of different IPR regimes upon the rates of innovation appears also from broad historical comparisons. For example, based on the analysis of data from the catalogues of two nineteenth-century world fairs-the Crystal Palace Exhibition in London in 1851 and the 
Centennial Exhibition in Philadelphia in 1876-Moser (2005) finds no evidence that countries with stronger IP protection produced more innovations than those with weaker IP protection, though there is significant evidence of the influence of IP laws on the sectoral distribution of innovations. In weak IP countries, firms did innovate in sectors in which other forms of appropriation (e.g. secrecy and lead time) were more effective, whereas in countries with strong IP protection significantly more innovative effort went to the sectors in which these other forms were less effective. Hence, one can draw from Moser's study the interesting conclusion that patents' main effect could well be on the direction rather than on the rates of innovative activity. (And we have to remember that we are concerned not with just innovation per se, but welfareenhancing innovation. If the patent system shifts resources into research designed to innovate around a patent, the net welfare benefit may be negative.)

More generally, the evidence suggests that the relationship between patents and innovation depends on the very nature of industry-specific knowledge bases, on industry stages in their life cycles, and on the industrial structure. Various surveys highlight both the differences among sectors and the limited role that patents play in many sectors. Levin, Klevorick, Nelson, and Winter (1987), for instance, report that patents are by and large viewed as less important than learning curve advantages and lead time in protecting product innovation, and are the least effective among the means of appropriating returns from innovative investments for process innovations (see Table 1.1). Cohen, Nelson, and Walsh (2000) present a follow-up to Levin et al. (1987), also addressing the impact of patenting on the incentive to undertake R\&D. Again, they report on the relative importance of the variety of mechanisms used by firms to protect their innovations-including secrecy, lead time, complementary capabilities and patents: see again Table 1.1. The table suggests that the most effective instruments for product innovations are secrecy and lead time while patents are the least effective, with the partial exception of drugs and medical equipment. Interestingly, the most important reasons given for not patenting an innovation were (i) the difficulty of demonstrating novelty (that is, satisfying the conditions required to get a patent) (32 per cent), (ii) information disclosure ( 24 per cent), and (iii) ease of inventing around the patent ( 25 per cent).

The uses of patents also differ for "complex" and "discrete" product industries. Complex products industries are those in which a product is protected by a large number of patents while discrete product industries are those in which a product is relatively simple and therefore associated with a small number of patents. In complex product industries, patents are used to block rival use of components and acquire bargaining strength in cross-licensing negotiations. In discrete product industries, patents are used to block substitutes by creating patent "fences" (cf. Gallini, 2002; Ziedonis, 2004). 
Table 1.1 Effectiveness of appropriability mechanism in product and process innovations, 1983 and 1994 surveys, United States, 33 manufacturing industries

1.1(a). Product innovation

\begin{tabular}{lcccccccc}
\hline & \multicolumn{3}{c}{$\begin{array}{l}\text { Rank of importance of mechanisms, and number of industries in which a } \\
\text { mechanism achieved that rank }\end{array}$} \\
\cline { 2 - 10 } Mechanism & \multicolumn{2}{c}{ 1st } & \multicolumn{2}{c}{ 2nd } & \multicolumn{2}{c}{ 3rd } & \multicolumn{2}{c}{ 4th } \\
\hline & 1983 & 1994 & 1983 & 1994 & 1983 & 1994 & 1983 & 1994 \\
Patents & 4 & 7 & 3 & 5 & 17 & 7 & 9 & 4 \\
Secrecy & 0 & 13 & 0 & 11 & 11 & 2 & 22 & 5 \\
Lead time & 14 & 10 & 14 & 8 & 5 & 7 & 0 & 7 \\
Sales \& service & 16 & 4 & 16 & 4 & 1 & 7 & 0 & 10 \\
Manufacturing & n.a. & 3 & n.a. & 3 & n.a. & 14 & n.a. & 7 \\
\hline
\end{tabular}

1.1(b). Process innovation

\begin{tabular}{lcccccccc}
\hline & \multicolumn{3}{l}{$\begin{array}{l}\text { Rank of importance of mechanisms, and number of industries in which a } \\
\text { mechanism achieved that rank }\end{array}$} \\
\cline { 2 - 9 } Mechanism & \multicolumn{2}{c}{1 st } & \multicolumn{2}{c}{ 2nd } & 3rd & \multicolumn{2}{c}{4 4th } \\
\hline & 1983 & 1994 & 1983 & 1994 & 1983 & 1994 & 1983 & 1994 \\
Patents & 2 & 1 & 4 & 5 & 3 & 3 & 24 & 16 \\
Secrecy & 2 & 21 & 10 & 10 & 19 & 1 & 2 & 0 \\
Lead time & 26 & 3 & 5 & 7 & 2 & 16 & 0 & 3 \\
Sales \& service & 4 & 0 & 16 & 0 & 7 & 3 & 6 & 11 \\
Manufacturing $^{*}$ & n.a. & 10 & n.a. & 12 & n.a. & 10 & n.a. & 0 \\
\hline
\end{tabular}

The table shows the relative importance of each mechanism (e.g. patents) to appropriability in 33 different sectors. The column on the left lists the various mechanisms. The other columns list the possible ranking of their importance to appropriability (1st, 2nd, 3rd, or 4th), and the number of sectors in which a mechanism held that rank of importance for appropriability, in 1983 and 1994 respectively. *Manufacturing capabilities. Source: Levin et al. (1987) and Cohen, Nelson and Welsh (2000) as presented in Winter (2002) (n,a. for observations not available).

It is interesting also to compare Cohen, Nelson and Walsh (2000) with the older Levin et al. (1987), which came before the changes in the IPR regime and before the massive increase in patenting rates. Even with this increased use of patents, Cohen, Neison and Walsh (2000) report that patents are not the key means to appropriate returns from innovations in most industries. Secrecy, lead time and complementary capabilities are often perceived as being more important appropriability mechanisms.

\section{The example of the semiconductor and other ICT industries}

Given that patents clearly play different roles in different industries, further insights can be gleaned by in-depth studies of particular industries. A number of scholars (Bessen and Maskin, 2000; Hall and Ziedonis, 2001) have focused

on the role of sectors of the that compute innovative ind protection and and fast-pace pattern. But $t$ rapid strength suggest that ". stronger prope among those $i$ Maskin (2000) tries character a previous one research lines reached). A p the use of the sequential wor ation rates. $\mathrm{Co}$ an environmer imitation wou imitation woul further profita

In these sec use of patents different firms

Again, the likely to be lim the social valu

In several resp role of IPR. It important mec is most affecte appropriation Open Science. in Angell, 200

But the tigh of innovationical Entities ( 
4th

\begin{tabular}{|c|c|}
\hline 1983 & 1994 \\
\hline 9 & 4 \\
\hline 22 & 5 \\
\hline 0 & 7 \\
\hline 0 & 10 \\
\hline 1.a. & 7 \\
\hline es in & ich a \\
\hline & \\
\hline 1983 & 199 \\
\hline 24 & 16 \\
\hline 2 & 0 \\
\hline 0 & 3 \\
\hline 6 & 11 \\
\hline n.a. & $u$ \\
\hline
\end{tabular}

ility in 33 different possible ranking of which a mechanism cturing capabilities. ter (2002) (n.a. for

000 ) with the PR regime and creased use of tre not the key stries. Secrecy, as being more

\section{ndustries}

ustries, further ries. A number 1) have focused on the role of patents in the semiconductor industry, one of the most dynamic sectors of the economy in recent decades. Bessen and Maskin (2000) observe that computers and semiconductors, while having been among the most innovative industries in the last forty years, have historically had weak patent protection and rapid imitation of their products. The short product life cycles and fast-paced innovation also may have played a role in this historical pattern. But then the software industry in the United States experienced a rapid strengthening of patent protection in the $1980 \mathrm{~s}$. Bessen and Maskin suggest that "far from unleashing a flurry of new innovative activity, these stronger property rights ushered in a period of stagnant, if not declining, R\&D among those industries and firms that patented most" (2000: 2). Bessen and Maskin (2000) argue that this phenomenon is likely to occur in those industries characterized by a high degree of sequentiality (each innovation builds on a previous one) and complementarity (the simultaneous existence of different research lines enhances the probability that a goal might be eventually reached). A patent, in this perspective, actually prevents non-holders from the use of the idea (or of similar ideas) protected by the patent itself and in a sequential world full of complementarities this turns out to slowdown innovation rates. Conversely, it might well happen that firms would be better off in an environment characterized by easy imitation, whereby it would be true that imitation would reduce current profits but it would also be the case that easy imitation would raise the probability of further innovation taking place and of further profitable innovations being realized later on. ${ }^{38}$

In these sectors, the growth in patents might have been associated with the use of patents as "bargaining chips" in the exchanges of technology among different firms and in the attempts of rent extraction from each other.

Again, the social value of research directed at obtaining such patents is likely to be limited, with the private value of such patents most likely exceeding the social value.

\section{Drugs: a second example}

In several respects, pharmaceuticals are an archetypical case for examining the role of IPR. It is one of the sectors for which IPR represents one of the more important mechanisms for appropriability. It is also the sector in which research is most affected by the Bayh-Dole Act and more generally by the exclusive appropriation of the results of research itself and the retreat of the boundaries of Open Science. It represents a sort of crucial institutional experiment (more on it in Angell, 2004; Mazzucato and Dosi, 2006; and Avorn, 2004).

But the tightening of the patenting regime was followed by a fall in the rate of innovation-as proxied e.g. by the number of FDA-approved New Chemical Entities (NCE) per year. ${ }^{39}$ While a good deal of the new discoveries were 
and are based on research funded by or conducted by government agencies (Angell, 2004), a big sbare of early discoveries appropriated by biotech firms and "big pharma" companies have remained unfulfilled promises of new drugs, that is they never went all the way to clinical trials. Part of the explanation of the seeming lack of innovation is that meaningful innovations are only part of the drug companies' concern: currently, marketing, enforcement of IPR-related rent extraction and search of me-too drugs (that is, marginal variations on incumbent, typically mass-market drugs for high income patients), all have a big share of major pharmaceutical companies' activities, while the uncertain experimentation of NCE, possibly effective only for subsets of patients with a certain disease, is far from a priority. All this is a powerful test-and indeed a very expensive one for the taxpayer and purchaser of health care services-of the ineffectiveness, at best, of tightening and widening IPR as an incentive to greater efforts of innovative search, even in the presence of seemingly increasing science-driven notional opportunities.

Part of the explanation of the failure of tighter IPR to enhance innovation may be the impediments that are posed for follow - on research and the adverse effects of the "institutional innovations" on the research process itself, by encouraging more secrecy. Part may rest in the effect that it had on the directions of search in favor of high-end, not-too-difficult to find "blockbusters" and subsidized me-too drugs, addressing rich and aging populations. ${ }^{40}$

As we shall discuss below, the picture is bleaker for developing countries.

\section{The role of appropriability more generally}

So far we have primarily discussed the relations between the regimes of IPR protection and rates of innovations, basically concluding that either the relation is not there, or if it is there that it might be a perverse one, with strong IPR enforcement actually deterring innovative efforts.

However, we also know that IPR protection is only one of the mechanisms for appropriating returns from innovation, and certainly not the most important one. We should, then, also consider the impact of appropriability more generally. The question is not whether an increase in the extent of appropriability increases investments in innovation in some sort of partial equilibrium model, given the inflow of knowledge. The question is what the broader impacts of stronger conditions for appropriability are, taking into account how they affect both incentives for investments and the dissemination of knowledge. In particular, stronger appropriability implies that the pool of "ideas" that are publicly available for researchers to draw upon may be smaller, and since technological opportunities are a (perhaps the) major driver of innovation, a reduced set of opportunities may actually lead to reduced innovation.

Considering together the evidence on appropriability from survey data (cf. Cohen, Nelson and Walsh, 2000; and Levin, Klevorick, Nelson and

Winter, (cf. Kleve tiple sour cf. Dosi, appropri: most a lis zero app vanish-c discussior appropria never per source so be very lo

\section{Oppo}

There are and empi tion and obvious $t$ not) of " theoretica appropria by means resources the rates a As Jaffe empirical ening of ir ation proc

Indeed, effect on ir

to the ext innovatio property the evider these effe

But if IPR ation, the 
ent agencies iotech firms ises of new part of the innovations ng, enforceugs (that is, igs for high companies' ffective only . All this is a rer and purhtening and 1 , even in the ities.

e innovation d the adverse ess itself, by had on the d "blockbuspulations. ${ }^{40}$ g countries.

jimes of IPR at either the se one, with

mechanisms most importiability more of appropria1 equilibrium ader impacts unt how they nowledge. In eas" that are er, and since innovation, a tion.

survey data Nelson and
Winter, 1987), the cross-sectoral evidence on technological opportunities (ct Klevorick, Levin, Nelson and Winter, 1995) and the evidence from multiple sources on the modes, rates and directions of innovation (for two surveys, cf. Dosi, 1988; and Dosi and Nelson, 2010), the broad conclusion is that appropriability conditions above a minimum threshold generally have at most a limited effect on the level and pattern of innovation. Obviously, with zero appropriability, the incentive to innovate for private actors would vanish-everybody would want to be a free rider-but, as our previous discussion emphasized, with few exceptions innovators are always able to appropriate some returns from their innovations; flows of information are never perfect; and technological knowledge is often quite sticky indeed. Open source software shows that the threshold level of appropriability might indeed be very low.

\section{Opportunities, capabilities and greed: some general properties of the drivers of innovation and its private appropriation}

There are some basic messages from the foregoing discussion of the theory and empirical evidence on the relationship between the extent of IPR protection and rates of innovation. For corporate investments in research, it is obvious that there must be some private expectation (whether fulfilled or not) of "profiting from innovation." Nevertheless, there are neither strong theoretical reasons nor strong empirical evidence suggesting that modifying appropriability mechanisms for innovations in general-and appropriability by means of IPR in particular-has any clear, strong effect on the amount of resources that private, self-seeking agents devote to innovative search, nor on the rates at which they discover new products and new production processes. As Jaffe concluded after surveying the available literature, "there is little empirical evidence that what is widely perceived to be a significant strengthening of intellectual property protection had significant impact on the innovation process" (2000: 540).

Indeed, we have explained why "stronger" IPR may actually have an adverse effect on innovation. Again, as Jaffe concluded:

to the extent that firms' attention and resources are, at the margin, diverted from innovation itself toward the acquisition, defence and assertion against others of property rights, the social return to the endeavour as a whole is likely to fall. While the evidence on all sides is scant, it is fair to say that there is at least much evidence of these effects of patent policy changes as there is evidence of stimulation of research. (2000: 555; see also $\mathrm{Hu}$ and Jaffe, Chapter 3 in this volume)

But if IPR regimes have, at best, second-order effects on the rates of innovation, the question remains of what the main determinants of the rates 
and directions of innovation are. Our basic answer, as argued in more detail elsewhere (cf. Cimoli, Dosi, and Stiglitz, 2009; and Dosi and Nelson, 2010) is the following. The fundamental determinants of observed rates of innovation in individual industries/technologies appear to arise from the extent of the opportunities that each industry faces. To understand this, it may be useful to think of an "opportunity sea" in which incumbents and entrants go fishing for innovation. A broader, deeper, richer sea contains more opportunities for innovation, stemming from a variety of sources. In part, they are generated by research institutions outside the business sector. Others spring from the search efforts incumbent firms have undertaken in the past. Moreover, yet others are generated and flow through the economic system via the relationships between suppliers and users ${ }^{41}$ (see the detailed inter-sectoral comparisons and taxonomy in Pavitt, 1984, and Klevorick, et al., 1995). But patents restrict the flow of knowledge into the "opportunity sea," and in doing so, have an adverse effect on the most important determinant of progress. Conversely, in most industries, the possibilities for appropriating returns--even with a weak IPR regime--are sufficient to induce firms to go out to "fish in the sea of opportunities."

In short, a full analysis has to take into account not just the effect of an IPR regime in inducing more innovation given the set of technological opportunities, but how a tighter IPR regime enables successful innovators to "enclose the commons," which reduces the amount of knowledge in the knowledge pool that could be the basis for further patentable research; as well as reducing the extent to which the induced innovations contribute to the pool of knowledge from which others may eventually draw. Tighter IPR regimes enable innovators to take more out of the pool and to contribute less to the pool, so that the size of the pool is diminished, so much so that the actual level of innovation may be diminished (Stiglitz, 2013c).

Indeed, one observes large differences in the innovative activity of different firms having little to do with any legal regime governing the access to the use of supposedly publicly disclosed but legally restricted knowledge, such as that associated with patent-related information. While the "rates of fishing" depend essentially on the size and richness of the sea, idiosyncratic differences in the rates of success in the fishing activity itself depend to a large extent on firm-specific capabilities. ${ }^{42}$ Increasing appropriability has little effect-given a particular level of capabilities and opportunities-upon the rates of investment and R\&D spending. And if that is so, then the adverse effects of stronger IPR on the technological opportunity set may dominate any positive effect of a change in how much society decides to compensate the fishermen for their catch. (Tighter IPR may itself impede the diffusion of learning capabilities among firms, thereby further diminishing the overall pace of innovation.)

While the effects of a stronger IPR regime on innovation are ambiguous, its effects on distribution are not. It gives rise to monopoly power. This leads to

\section{Int}

higher prices a But in some se even worse: $h$ higher drug pr more question

We should, matter. It is no design. We ha United States the IPR regim regime (and $\mathrm{C}$ effects. For ins some of the a adverse budge laws would re practices of th more general U.S. IPR regin reducing the $\mathrm{s}$

A country's in innovation; it viduals and co resources amo concerned wit the economy, $i$ production pro

There are $\mathrm{m}$ property rights Much research on within uni laboratories, ty the private sect

In evaluating ultimate object well-being nov direction of in research are us for instance, af 
more detail on, 2010) is innovation xtent of the ay be useful ts go fishing pportunities re generated ng from the ioreover, yet the relationral compariBut patents oing so, have . Conversely, -even with a in the sea of

fect of an IPR cal opportunrs to "enclose he knowledge ell as reducing ool of knowegimes enable o the pool, so actual level of

ity of different cess to the use e, such as that of fishing" dedifferences in arge extent on effect-given a ates of investects of stronger sitive effect of a rmen for their ing capabilities innovation.) ambiguous, its r. This leads to higher prices and lower consumer welfare (at any given level of innovation). ${ }^{43}$ But in some sectors, like pharmaceuticals, the adverse effects of patents can be even worse: how are we to evaluate the unnecessary deaths associated with higher drug prices? ${ }^{44}$ As a result, the overall benefits of stronger IPR are even more questionable.

We should, of course, bear in mind our earlier important message: details matter. It is not only a matter of the "strength" of the IPR regime, but also its design. We have described some of the effects of the IPR regimes that the United States and other countries have had, and how some of the changes in the IPR regime have affected innovation. There are some changes in the IPR regime (and other associated legal regimes) that would reduce the adverse effects. For instance, more extensive use of compulsory licensing would reduce some of the adverse welfare effects from unnecessary deaths and from the adverse budgetary consequences; more effective enforcement of competition laws would reduce some of the adverse welfare effects from anticompetitive practices of those who attempt to leverage the monopoly of the patent into more general market power. Later, we will describe a recent change in the US IPR regime that may reduce the adverse effects of the patent thicket, by reducing the scope for holdups.

\section{PATENTS AND A COUNTRY'S INNOVATION SYSTEM ${ }^{45}$}

A country's innovation system is the collection of institutions that promote innovation; it fosters the accumulation of technological capabilities in individuals and corporations; it provides incentives and finance, and allocates resources among researchers and research projects. The innovation system is concerned with the production and dissemination of knowledge throughout the economy, including the creation of new products and the improvement of production processes.

There are many components of an innovation system besides intellectual property rights (see e.g. Freeman (1987), Lundvall (2010) and Nelson (2004b).) Much research-and especially basic research, the most foundational-goes on within universities, not-for-profit research institutions, and government laboratories, typically financed by government, sometimes in partnership with the private sector, sometimes supported by foundations. ${ }^{46}$

In evaluating alternative innovation systems, there are several criteria. The ultimate objective is the well-being of society and its dynamics (that is, not just well-being now, but in the future). That, in turn, is affected by the pace and direction of innovation and the efficiency with which resources devoted to research are used. But the innovation system does not exist in isolation. It can, for instance, affect the competitiveness and efficiency of the entire economy, 
the extent of inequality in society and the health of its citizens. It can even have large budgetary consequences, as in the United States, as government pays pharmaceutical companies large amounts for drugs, the production costs of which are but a fraction of what the government pays-in some cases, even for drugs based largely on government-financed research.

In recent years, two other institutional arrangements (besides IPR and government supported research) have grown (and regrown) in importance as part of a modern innovation system: prizes and open source.

The prize system represents one alternative to the patent system for providing incentives for research. This entails giving a prize to whomever comes up with an innovation, or at least those innovations that meet announced objectives. For instance, the person who finds a cure or a vaccine for AIDS or malaria would get a big prize. Someone who comes up with a drug with slightly different side effects than existing drugs (but which is otherwise no more effective) might get a small prize. The size of the prize is calibrated by the magnitude of the contribution.

The idea is an old one. The UK's Royal Society for the Encouragement of Arts, Manufactures and Commerce has been advocating and using prizes to incentivize the development of needed technologies for more than a century. For instance, an alternative was needed for chimney sweeps, those small, underfed boys who used to be sent down chimneys. It was not good for their health, but not cleaning chimneys meant increasing the risk of fire, with serious consequences. So the Royal Society offered a prize to anybody who invented a mechanical way of cleaning chimneys. The prize provided an incentive-and it worked. A patent system might also have motivated the development of a mechanical device (though it did not), but if it had, there would have been a problem: the owner of the patent would have wanted to maximize the return on his innovation by charging a high fee for its use. That would have meant that only rich families could have afforded to use the mechanical device, and young boys' lives would have continued to be put at risk. With the prize system, everyone ended up henefitting from this socially important innovation.

The current patent system is, of course, similar to a prize system, but it is an inefficient one, hecause the "prize" is a grant of monopoly power, and with monopoly power there are incentives to restrict the use of the knowledge. One of the characteristics of a desirable innovation system is that the ideas and innovations, once developed, are widely used and disseminated; to the contrary, the patent system is designed to restrict the use of knowledge. With the prize system, a competitive market ensures a reasonably efficient dissemination: giving licenses to a large number of actors enables competition to drive down the price and to increase the use of the knowledge. With both patents and prizes, market forces are used: one is the incentive of a monopoly to 
s. It can even have government pays roduction costs of me cases, even for

(besides IPR and n) in importance urce.

it system for prowhomever comes meet announced cccine for AIDS or with a drug with th is otherwise no $s$ calibrated by the

Encouragement of nd using prizes to re than a century. eeps, those small, was not good for $\mathrm{g}$ the risk of fire, prize to anybody prize provided an ave motivated the ut if it had, there $d$ have wanted to ee for its use. That forded to use the inued to be put at from this socially

system, but it is an power, and with e knowledge. One hat the ideas and nated; to the con owledge. With the fficient disseminmpetition to drive With both patents of a monopoly to restrict knowledge and raise prices, the other is the force of competitive markets to drive down prices and extend the benefit of knowledge widely.

Moreover, the prize system has the advantage of creating fewer incentives to waste money on advertising and to engage in anticompetitive behaviors designed to enhance monopoly profits. Drug companies spend more on advertising and marketing than they do on research. ${ }^{47} \mathrm{Much}$ of these marketing expenditures are designed to reduce the elasticity of demand, which allows the owner of the patent to raise prices and increase monopoly profits. From a social point of view, these expenditures are dissipative.

The patent system also distorts the pattern of research: drug companies have insufficient incentives to develop medicines for the diseases that tend to afflict poor people, simply because there is no money in those drugs. ${ }^{48}$ And as we have already noted, there are other distortions: incentives for research to get a share of the rents through me-too patents, to extend the life of the patent, through evergreening, to get "blocking" patents that can extract rents in holdups.

The fourth alternative way of promoting innovation, open source, has become especially important in IT, but has spread from there to other sectors (see Henry and Stiglitz, 2010; Hertel, Krishnan and Slaughter, 2003; Lerner and Tirole, 2002; Weber, 2005). It highlights and strengthens the collaborative nature of research that is the hallmark of academia, and the open architecture facilitates follow-on research, in contrast to the patent system which closes it down. As in academia, in some instances non-pecuniary returns play a crucial role in motivating research; in other cases, firms have found a variety of ways of appropriating returns, e.g. through the sale of services or tailoring software based on open source to the needs of particular clients.

There is still a fifth alternative, already described: let firms appropriate returns through natural markets using the non-IPR mechanisms (the advantage of being first, etc.) described earlier.

Table 1.2 provides a chart of some of the attributes of the five alternatives we have described.

Any innovation system has to solve the problems of finance, selection (who gets research money) and incentives. There are, in addition, problems of coordination of research efforts. How these tasks are solved will affect the efficiency of the system-including the uncertainty and transaction costs facing market participants. Every country should have a portfolio of instruments, but in our view, too much weight has been assigned to patents in the current U.S. portfolio.

The first attribute listed is selection. One problem facing any innovation system is how to select those to engage in research activities. A possible advantage (but also a possible bias) of both the patent and prize system is that they are decentralized and based on self-selection. Those who think that they are able to successfully undertake the research in a particular 
Table 1.2 Comparing alternative systems

\begin{tabular}{|c|c|c|c|c|c|}
\hline \multirow[b]{2}{*}{ Attribute } & \multicolumn{5}{|l|}{ Innovation system } \\
\hline & Patent & Prize & $\begin{array}{l}\text { Government-funded } \\
\text { research }\end{array}$ & Open source & $\begin{array}{l}\text { Non-IPR market } \\
\text { appropriation }\end{array}$ \\
\hline Selection & $\begin{array}{l}\text { Decentralized, self- } \\
\text { selection. }\end{array}$ & $\begin{array}{l}\text { Decentralized, self- } \\
\text { selection. }\end{array}$ & Bureaucratic. & Decentralized, self-selection. & $\begin{array}{l}\text { Decentralized, self- } \\
\text { selection. }\end{array}$ \\
\hline & $\begin{array}{l}\text { Lacks } \\
\text { coordination. }\end{array}$ & Lacks coordination. & $\begin{array}{l}\text { More coordination } \\
\text { possible. }\end{array}$ & $\begin{array}{l}\text { Sometimes "self" } \\
\text { coordination. }\end{array}$ & Lacks coordination. \\
\hline Finance $(\operatorname{tax})$ & $\begin{array}{l}\text { Highly } \\
\text { distortionary and } \\
\text { inequitable. }\end{array}$ & $\begin{array}{l}\text { Can be less } \\
\text { distortionary and more } \\
\text { equitable. }\end{array}$ & Most efficient. & $\begin{array}{l}\text { May be underfinanced. } \\
\text { Foundations, government, } \\
\text { by-product of other activities. }\end{array}$ & $\begin{array}{l}\text { Likely to be less } \\
\text { distortionary than patent. }\end{array}$ \\
\hline Risk & Litigation risk. & Less risk. & Least risk. & Limited. & Limited. \\
\hline Innovation incentives & $\begin{array}{l}\text { Strong but } \\
\text { distorted. }\end{array}$ & $\begin{array}{l}\text { Strong, less distorted. } \\
\text { Requires well-defined } \\
\text { objectives. }\end{array}$ & $\begin{array}{l}\text { Strong non-monetary } \\
\text { incentives. }\end{array}$ & Strong-often non-pecuniary. & Strong, less distorted. \\
\hline Dissemination incentive & $\begin{array}{l}\text { Limited- } \\
\text { monopoly. }\end{array}$ & $\begin{array}{l}\text { Strong-competitive } \\
\text { markets. }\end{array}$ & Strong. & Strong. & $\begin{array}{l}\text { Limited-returns depend } \\
\text { on secrecy. }\end{array}$ \\
\hline Transaction costs & High. & Lower. & Lower. & Low. & Low. \\
\hline
\end{tabular}


technological field make the investment, risking their own money, in the belief that they have a good chance of winning the prize (the formal prize or the prize of the patent). This would seem to be a significant advantage of the prize and patent systems over government-funded research, in which there is a group of peers (or bureaucrats) deciding on the best searchers. ${ }^{49,50}$ In some countries, there is obviously also a concern about "capture" of the researchawarding process, e.g., by political or economic interests whose agendas may be separate from or counter to the advancement of science and technology. At the same time, self-selection does not necessarily result in the best researchers undertaking research, but rather the most confident, or those with the deepest pockets. Thus, patent races and prizes put smaller firms at a disadvantage. To the extent that those that enter the fray are those that are the most overconfident, though innovation might proceed more slowly than it would in an alternative system, at least the costs of the mistakes are not borne by the public.

With respect to finance, the patent system is the worst of the systems. It is highly distortionary and inequitable in the way in which funds to support research are raised-by charging monopoly prices, e.g., in the case of pharmaceuticals, on the sick.

By the same token, the transaction costs (especially those associated with litigation) and the distortions in the economic system are much higher with a patent system than with the other two. (And there is some evidence that those costs are increasing, together with the firms ${ }^{3}$ propensity to litigate. $)^{51}$

Regarding the dissemination of knowledge and its efficient use, government-funded research, the prize system and open source are best (because knowledge is generally made freely available), and the patent system is the worst, given that it relies on monopolization, which entails high prices and restricted usage. In short, under the prize and the government-funded research systems, knowledge, once acquired, is more efficiently used. These are among the key advantages of these alternatives.

There is a big difference in the nature of the risk faced by researchers (which in modern economies often happen to be firms) operating in the different systems. With respect to risk, the patent system is the worst and the government-funded system is the best, because it has the advantages of paying for the input rather than the output. That is to say, a researcher gets money for his time and other resources spent doing the research, whereas in the prize and the patent systems researchers are rewarded only if their research is successful-and successful before their rivals.

Risk is increased too within the prize and patent system by problems of coordination. One of the disadvantages of both the patent and the prize systems is the lack of coordination. The lack of coordination reduces the efficiency of the innovation process and increases risk. The difficulties of 
coordination are increased by secrecy which is encouraged by the IPR regime. Relatedly, one of the risks that each researcher faces is that of costly litigation.

One of the reasons that risk (in fact, most often in the case of innovation, "Knightian" uncertainty which cannot be reduced to objective probabilities) is important is that users and consumers ultimately have to pay for the risk borne by researchers. People and firms $\mathrm{s}^{52}$ tend to be risk averse, and if they must bear risk, they demand to be compensated for doing so (through higher prices and mark-ups). The patent system makes society bear the cost of that risk in an inefficient way. Under the government-financed research system, not only is risk lower, but it is shared by society in a more efficient way.

Innovation incentives are strong in the patent system, but they are distorted. The prize system can provide strong incentives, but the incentives are designed to foster socially desirable innovation, in contrast to the distorted incentives of the patent system, discussed earlier in this introduction. ${ }^{53}$

On most accounts, the prize system dominates the patent system; but the prize system has one limitation: it does not work when the objective is not well-defined. There are, however, many areas, such as health, energy conservation and carbon emissions reductions, in which there are well-defined objectives. The prize system will never fully replace the patent system. At the same time, in basic research-the foundation on which everything else is built-government-funded research will continue to remain at the core of the innovation system. It would be a disaster otherwise: the costs of restricting the usage of more basic knowledge associated with the patent system far outweigh any purported benefits.

\section{IPR IN THE DEVELOPMENT PROCESS}

What we have said so far applies to countries more or less on the "technological frontier." The drawbacks of IPR, especially poorly designed IPR regimes, are significantly amplified when tight IPR regimes are applied in countries attempting to catch up with the more advanced industrial countries. As we note in the preface, what separates developed from developing countries today is as much a gap in knowledge as a gap in resources. Access to knowledge is essential. But the intellectual property regime denies them access to knowledge and/or requires that they pay large rents to firms in the developed countries.

This is a core topic of this book analyzed from different angles, especially in the Chapters 2, 3, 4 and 7 of this volume and also in Odagiri, Goto, Sunami 
$y$ the IPR at of costly

nnovation, abilities) is or the risk and if they ugh higher cost of that rch system, it way. re distorted. ives are dene distorted ion. $^{53}$

tem; but the ective is not ergy conserwell-defined system. At thing else is e core of the estricting the far outweigh

\section{S}

the "techno" designed IPR re applied in rial countries. ping countries es. Access to es them access in the devel-

s, especially in Goto, Sunami

and Nelson (2010), which is in many respects complementary to this one, as it takes a historical perspective of inter-country comparisons.

"Tight" intellectual property rights regimes tend to hinder the development of local technological capabilities in general and absorptive capabilities in particular, since they hinder the activities of reverse engineering and imitative experimentation which are typically at the core of the development process.

As discussed in the introduction to Odagiri et al. (2010), and also in Chapters 2 and 16, learning in catching-up countries takes place mainly via the following (partly complementary) mechanisms:

(i) Mobility of people either in the form of the "peaceful conquest" (Pollard, 1981), i.e. the emigration of technicians from frontier countries to catching-up ones-as it occurred in the nineteenth century in Continental Europe and the United States, with many coming from the U.K.; or in the form of students and technicians coming for periods of training in Europe and the United States from Japan and later South Korea, China, etc. and then returning back home.

(ii) Open source forms of knowledge dissemination, including exhibitionsquite important in the nineteenth century-conferences, papers, more recently internet and even patent documents.

(iii) Investment goods-especially machine tools and instruments-that "embody" advances in knowledge. Knowledge is also transmitted and developed as those in the catching-up countries learn how to effectively use these advanced investment goods.

(iv) Imitation, reverse engineering, or sheer copying of foreign products and capital inputs by domestic firms.

(v) Formal licensing of patented technologies and know-how by domestic firms.

(vi) Inter-firm technology transfer by MNCs to their subsidiaries in emerging economics.

(vii) Technological spillovers from MNCs themselves to other firms in catching-up countries, especially as a result of the training of workers.

In addition, several emerging markets (particularly China and Brazil) have become a source of innovations in their own right. In some areas, they have moved to the frontier: China, for instance, in solar technology; Brazil in deepwater drilling for oil and sugar-based ethanol. Patent grants to residents of China have soared in recent years, from 5,395 in 2001 to 112,347 in $2011 .^{54}$

The reason we have provided this long list of channels through which the knowledge gap is reduced is that Western advocates of IPR emphasize only a few channels that might be enhanced by stronger IPR-including MNCmediated and license-mediated transfer of technology. But IPR may have 
adverse effects on other channels (e.g. those associated with the transfer of knowledge/products/processes via imitation and learning from developed to developing countries). Indeed, the historical record shows that these other mechanisms have typically been paramount in successful episodes of industrialization (more in Cimoli, Dosi and Stiglitz, 2009). ${ }^{55}$ And if the latter are more important (as they probably are in most developing countries), then negative effects outweigh the positive. In fact, the evidence that stronger IPR regimes are effective in fostering technology transfer is far from conclusive (more in Fink and Maskus, 2005; Odagiri et al., 2010; Hu and Jaffe, Chapter 3 in tbis volume).

\section{THE IMPACT OF TRIPS}

TRIPS bas brought increased international harmonization. But is it likely to bring increased innovation to developing countries? Was there excessive harmonization? And was the harmonization around the rigbt standards?

We suggest that this new IPR regime tends to be, other things being equal, a hindrance to the process of development and catching-up, precisely because it impedes many of the ways by which knowledge is transferred to developing countries: it tends to hinder, for instance, imitation by domestic firms and accumulation of local technological capabilities. These were indeed the instruments which developed countries-from the United States, to Germany, to Japan-used abundantly during the course of their catching up. Interestingly, later, those same countries "kicked away the ladder" (Chang, 2002), re-writing history as they sought to depict their earlier success as a result of free-trade with strong IPR (more in Odagiri et al., 2010; and in Chapter 2 in this volume). ${ }^{56}$

For developing countries, there is a further concern: the "new" IPR regime may result in massive transfers of money from developing to developed countries (that, of course, was the intent when setting it up!). To reduce the gap in knowledge, developing countries are being asked to increase the gap in resources. Under the new TRIPS regime the flow of international licenses from developed to developing countries in monetary terms significantly increased (Maskus, 2005; Arora, Fosfuri and Gambardella, 2001). However it is less clear-cut whether this is due to an actual increase in the flow of technology transfers (the flow of knowledge) or in the costs of such transfers-that is, ultimately in the rents extracted out of the licensing of each piece of technological knowledge.

In some circumstances, such as in the pharmaceutical industry, the evidence is particularly striking. Before TRIPS, generics obtained under loose IPR regimes were able to dramatically reduce the cost of drugs available to 
Intellectual Property Rights in the Development Process

e transfer of developed to these other des of industhe latter are untries), then stronger IPR m conclusive ffe, Chapter 3

$t$ is it likely to nere excessive tandards? being equal, a isely because it to developing stic firms and leed the instruo Germany, to . Interestingly, 02), re-writing 1t of free-trade apter 2 in this

w" IPR regime g to developed . To reduce the rease the gap in al licenses from cantly increased wever it is less $w$ of technology ansfers-that is, piece of techno-

try, the evidence inder loose IPR ugs available to
Table 1.3 Costs of first and second line HIV treatments in Western and developing countries

\begin{tabular}{|c|c|c|c|}
\hline$\because$ & $\begin{array}{l}\text { Lamivudine/stavudine/ } \\
\text { nevirapine (1st line) }\end{array}$ & $\begin{array}{l}\text { Tenofovir/didanosine/ } \\
\text { opinavi (2ndline) }\end{array}$ & 2nd line vs. 1st line \\
\hline Western countries ${ }^{a}$ & U.S. $\$ 8,773 / \mathrm{yr}$ & U.S. $\$ 13,551 / \mathrm{yr}$ & $\begin{array}{l}1.5 \text { times more } \\
\text { expensive }\end{array}$ \\
\hline Developing countries & $\begin{array}{l}\text { U.S. } \$ 154 / \mathrm{yr} \\
\text { CiplaTriomune }^{\mathrm{b}}\end{array}$ & $\begin{array}{l}\text { U.S. } \$ 3,950 / \mathrm{yr} \\
\text { Originator product }\end{array}$ & $\begin{array}{l}26 \text { times more } \\
\text { expensive }\end{array}$ \\
\hline Reduction & $-98 \%$ & $-70 \%$ & \\
\hline
\end{tabular}

a Australian EXW prices: Schedule of Pharmaceutical Benefits for Approved Pharmacists and Medical Practioners, May 2004. Exchange rate used for conversion 1 AUD =0.72213 USD, 1 May 2004.

${ }^{b}$ Clinton Foundation price (FOB) $+10 \%$ due to transportation and importation taxes.

Source: E. t'Hoen (2005) and elaborations by Coriat, Orsi, and d'Almeida (2006).

developing countries. A vivid illustration concerns anti-retroviral drugs against the HIV virus where generics were able to reduce the cost by between 98 per cent and 70 per cent (cf. Table 1.3, from Coriat et al, 2006; and Chapter 7 in this volume).

More generally, the evidence discussed in Coriat and Orsenigo in this volume suggests that large increases in the prices of drugs in developing countries, ranging between 50 per cent and 400 per cent, resulted from the implementations of TRIPS. And all that, of course, without evidence that these higher prices have led either to more drug innovation in general, let alone more innovation attempting to address the needs of those in developing countries.

There are no major pharmaceutical companies in the developing world and a good deal of learning and catching-up-in India, Israel, Thailand, China and Brazil-occurred precisely with the production of generics, under loose IPR protection most often covering only processes of production but not products. And all this is now banned, or at least, significant barriers have been imposed to the introduction of generics, and so innovation in developing countries is impeded. (Note that the benefits of establishing a generics industry may go well beyond the lower prices; on the basis of the learning associated with generics, a broader industry can be established.)

Yet another archetypal case is agriculture. If one takes the long-term view as the chapters by Nuvolari and Tartari, and by Halewood do--this is a sector where technological improvements have taken place over decades and centuries, in the absence of any IPR protection, though at a slower pace until the nineteenth century, when-still without any IPR protection-dramatic agricultural advances occurred (allowing a small proportion of the labor force to produce all of the food demanded even as incomes rose), significantly helped by public institutions such as Land Grant Colleges in the United States and similar ones in Europe. 
The scenario changed a good deal with the introduction of high-productivity, (quasi-) sterile seeds. The originators of innovation began to successfully demand a powerful "technical protection" on the flow of outputs from their innovations. Chapter 9 in this volume explores the difference between "if you want a seed as productive as last year, you are bound to come back to me, and at my prices" as compared to "if you buy the seeds which I originated, without paying some royalty to me I will bring you to court in Burkina Faso." The outcome, as Swanson and Goeschl highlight, is much lower rates of innovation diffusion and a greater divergence vis-à-vis the moving international productivity boundaries-no matter how measured.

\section{An intellectual property regime for developing countries}

This book offers a detailed diagnostics of the impact of IPR on developing countries at multiple levels-including the rates and direction of scientific search and technological innovation, the rates and patterns of international diffusion of technological knowledge, and more generally its effects on the developing countries' catching-up process.

At the same time, this book is equally rich in the exploration of policy measures fostering the international diffusion of knowledge, the accumulation of capabilities in catching-up countries and the access by the populations in emerging economies of the fruits of technological innovation. Chapter 6 draws upon U.S. experiences in formulating policy lessons for governance of publicly financed research by developing countries. Chapter 7 discusss the policy agenda in the area of pharmaceuticals in the post-2005 international TRIPS regime. Chapter 10 analyzes the possibilities of securing a global common in plant genetic resources, while Chapter 11 deals with the ways of nurturing open source modes of governance of biotech knowledge in emerging economies. Chapter 12 examines the role of IPR with respect to innovations curbing greenhouse gases in general, and in developing countries in particular, while Chapter 13 considers different arrangements aimed at the diffusion to the developing countries of environmentally sound technologies.

Finally, the last three chapters look at IPR and their consequences from the point of view of the international governance institutions and the role of IPR policies in the broader context of industrial policies. Chapter 14 discusses in depth the "opportunities" (i.e. the "flexibilities") still available to developing countries under the TRIPS regime, opportunities which bilateral and multilateral trade agreements attempt to restrict, as Spenneman and Roffe show in Chapter 15. Burlamaqui and Cimoli in Chapter 16 continue in this vein, exploring links between IPR, industrial policy, and the reach and limits of the "governance of knowledge."
We have s
policies, and
within the br
component.
are industrial
and organiza
ly, the 1995
that was not
developing co
We shall
this book.

Everywhere, and the econc one between corporations interests, bat property is $\mathrm{m}$ be large distri impede inno patent lawyer

It is not ju. by the courts of this introd courts and a dangers of un

The first is eBay Inc. v. I enforced thro the permissio wishes. This i for violating $\mathrm{s}$ questions abo ment though might infring injunction (as satisfied: 
gh productivity, to successfully puts from their between "if you back to me, and rinated, without ina Faso." The es of innovation tional product-

\section{untries}

on developing on of scientific $f$ international effects on the

tion of policy accumulation populations in hapter 6 draws nce of publicly sss the policy ational TRIPS al common in of nurturing nerging econinnovations in particular, e diffusion to nces from the ie role of IPR 4 discusses in to developing al and multiRoffe show in in this vein, and limits of
We have suggested that excessive attention has been given to IPR-related policies, and that more progress would have been made if IPR had been viewed within the broader context of an innovation system, of which IPR is only one component. Equally or more important from the perspective of "catching up" are industrial policies focusing on the development of domestic technological and organizational capabilities. This is the thrust of Chapter 16. Unfortunate1y, the 1995 Uruguay Round not only created an intellectual property regime that was not pro-development, but also imposed restrictions on the ability of developing countries to effectively use industrial policies.

We shall come back to several of these policy themes in the conclusion to this book.

\section{RECENT DEVELOPMENTS IN IPR AND INNOVATION SYSTEMS}

Everywhere, intellectual property rights are in flux, as changes in technology and the economy pose challenges to existing perspectives. The battle is not just one between civil society and consumer groups, on the one hand, and large corporations on the other. There is also a battle among different business interests, battles that illustrate the central themes of this book-intellectual property is man-made, designed to enhance societal well-being, and there can be large distributive effects. But if we don't design the IPR system well, it may impede innovation. It may help large established firms, with their army of patent lawyers, at the expense of small firms.

It is not just the laws themselves that matter, but how they are interpreted by the courts and the agencies that administer them. In the concluding section of this introduction, we discuss two recent developments that illustrate how courts and administrative agencies are trying to come to terms with the dangers of unbalanced IPR regimes.

The first is a path-breaking decision of the Supreme Court in a case called eBay Inc. v. MercExchange, L.L.C. ${ }^{57}$ In the past, patents have typically been enforced through "injunctions"-others cannot trespass on a patent without the permission of the patent holder, who can extract as much "rent" as he wishes. This is in contrast with many other areas, where there is compensation for violating someone's rights or property. The Supreme Court itself has raised questions about the consequences of what might be termed excessive enforcement though actions by patent holders that in effect "exclude" those who might infringe upon the patent. In $e B a y$, the Court ruled that a permanent injunction (against infringement) would only be granted if a four-part test was satisfied: 
A [patent] plaintiff must demonstrate: (1) that it has suffered an irreparable injury; (2) that remedies at law, such as monetary damages, are inadequate to compensate for that injury; (3) that, considering the balance of hardships between the plaintiff and defendant, a remedy in equity is warranted; and (4) that the public interest would not be disserved by a permanent injunction.

An extreme version of exclusion is still part of America's trade laws, where a firm that the International Trade Commission finds has violated an American's intellectual property rights can have the infringing products excluded from importation into the United States. In 2012, a small company, X2Y, sued Intel, Apple and Hp to exclude all of Intel's advanced microprocessors, all of Apple's computers (which employ these microprocessors), and those HP computers that do so. The claim was that these microprocessors infringed, in their "packaging" on a X2Y patent. X2Y had offered to sell this and a bundle of other patents for a few million dollars. Intel viewed it as a holdup and refused. The cost to Intel, Apple and HP — let alone to the U.S. economyof the exclusion would have been in the order of billions of dollars. ${ }^{58}$

The law providing for the exclusion had a narrow exception-the exclusion order was not to be issued if it was against the public interest. But the ITC had so narrowly defined the exception that it had been used only four times in forty years. The irony, of course, was that a law designed to protect American firms against foreign firms who violated the intellectual property rights of Americans was being used by a small American firm that had spent a miniscule amount on research-and far more on lawyers-to hold up some of America's leading IT companies who were spending billions on research. Those who argued against the exclusion order contended that exclusion would not only have a large negative effect on the economy in the short run, but also that it would actually be counterproductive, inhibiting innovation.

The second example is from a developing country-India--and shows once again how the interpretation of laws can be critical. Before TRIPS, India had had a thriving generic drug industry. The patent laws that India passed as part of its implementation of the obligations it undertook as part of TRIPS had put this important industry in jeopardy. A recent Court decision refusing to grant a patent to a Western drug company provided new life, and not only for the generic drug industry. The lower price of drugs of the generics provided lifesaving medicines for those in the developing countries that otherwise would never have been able to afford them.

Earlier in this paper, we noted the influence of special interest groups in shaping the intellectual property regime. It is not designed to maximize innovation or societal well-being, even in the developed countries, but even less so in developing countries; rather, it is more concerned with maximizing rents to certain types of innovation activities. Even within TRIPS, developing countries have much more discretion than they have taken advantage of.
They should sh of their citizens their patents th able standard the standard v countries shou companies suc

Intellectual chapters in this advocates of st erty rights, the is too simplist summarized in innovation is $n$ that societal w multitude of ot and it ignores $t$ were more inno is increased: th monopoly pow be seen as part,

Because inno innovation is $\mathrm{C}$ But it should b States and Eurc necessarily be a

Our hope is tation to just a innovation syst will help them well-being of th

1. This introduct intellectual pro and Stiglitz (2 (2006). The a Poverty Cente ECLAC confer (29-30 Augus 
d an irreparable re inadequate to rdships between and (4) that the n.

ade laws, where a olated an Ameriroducts excluded apany, X2Y, sued processors, all of , and those HP essors infringed, $o$ sell this and a ed it as a holdup U.S. economydollars. ${ }^{58}$ n-the exclusion But the ITC had 1y four times in rotect American roperty rights of nat had spent a to hold up some ons on research. exclusion would lort run, but also ation.

-and shows once RIPS, India had ia passed as part f TRIPS had put refusing to grant not only for the enerics provided that otherwise

terest groups in ed to maximize intries, but even with maximizing RIPS, developing in advantage of.
They should shape the intellectual property regime to advance the well-being of their citizens. For instance, drug companies regularly try to extend the life of their patents through "ever-greening." But most such attempts fail a reasonable standard of "obviousness." It is, for example, obvious how to move from the standard version of a drug to the time release version. Hence, developing countries should not grant patents for the time release version, even if the drug companies succeed in getting developed countries to provide such patents.

Intellectual property is complex. If nothing else, this introduction, and the chapters in this book, should have convinced the reader that the mantra of the advocates of stronger IPR-that the stronger the system of intellectual property rights, the faster the pace of innovation-has itself no intellectual basis. It is too simplistic, partly because property rights are too multifaceted to be summarized in a simple linear way (from weaker to stronger), partly because innovation is multifaceted: even if there were more patents, it doesn't mean that societal welfare is necessarily increasing, partly because it ignores the multitude of other ways in which the returns to innovation are appropriated, and it ignores the multitude of other drivers of innovation. And even if there were more innovation, somehow defined, it doesn't mean that societal welfare is increased: the innovations could be directed at enhancing and extending monopoly power, at increasing rents or seizing other firms' rents. IPR needs to be seen as part, but only part, of a country's innovation system.

Because innovation is complex, designing a good IPR system that promotes innovation is complex-and perhaps even more so in developing countries. But it should be clear that an IPR system that is appropriate for the United States and Europe (even if they had a well-designed IPR system) would not necessarily be appropriate for developing countries.

Our hope is that this book will help developing countries resist the temptation to just adopt the IPR regimes of the advanced countries, to whose innovation system they aspire. Our hope too is that the insights it provides will help them design an IPR system that enhances their growth and the well-being of their citizens.

\section{NOTES}

1. This introduction is based in part on earlier work by the authors on the issues of intellectual property, and especially Stiglitz (2004, 2006, 2008, 2013a, 2013b), Henry and Stiglitz (2010), Dosi and Nelson (2010) and Dosi, Marengo and Pasquali (2006). The authors are indebted to the participants in the IPD/Brooks World Poverty Center conference in Manchester (8-10 September 2010) and in the IPD/ ECLAC conference, "Towards Inclusive Development in Latin America and Chile" (29-30 August 2011) for key insights into the issues described here, and to their 
many collaborators in their work on intellectual property. We would like to acknowledge the assistance of Ritam Chaurey and the financial support of the Institute for New Economic Thinking (INET), New York, and Scuola Superiore Sant'Anna, Pisa, Italy.

2. It should be clear that the term "trade-related" was only used to enable intellectual property to be included as part of a trade agreement. The thrust of trade agreements was to open borders to the free movement of goods and services (and in some cases factors); TRIPS was designed to restrict the free flow of knowledge. Interestingly, this critical view of TRIPS is even held by strong advocates of multilateral trade agreements. For a critique of the inclusion of intellectual property rights in trade agreements, see Stiglitz (2006) and Bhagwati (2004).

3. Statement by Brazil on 30 September 2004 before WIPO General Assembly at the introduction of the proposal for a development agenda.

4. The patents on basmati rice and the medicinal uses of turmeric were eventually overthrown, but the costs of litigation were significant (see Stiglitz, 2006 and Brand, 2005). Indeed, even the U.S. courts have recognized these costs. In United States v. General Electric Co., 115 F. Supp. 835, 844 (1953) the court, in arguing for compulsory licensing with zero royalties, noted that "small firms desiring to stay in or gain a foothold in the industry... may well be unequipped to engage in litigation on the validity of one patent after another at what could be incalculable expense. In order to avoid it they could be required to shoulder royalties which could prove to be the very factor that would push them out of the competitive circle of the market" (cited in Love, 2005). See Stiglitz (2006) and Perleman (2002).

5. Opposition of drug companies on this issue also underlay the reluctance of some developed countries besides the United States to ratify the bio-diversity convention. (See Henry and Stiglitz, 2010 for a brief discussion.)

6. From Stiglitz (2013a).

7. For a recent discussion of some of the controversies associated with intellectual property rights, see the winter, 2013 symposium of the Journal of Economic Perspectives.

8. That there is a large disparity between private and social returns has become increasingly recognized. See, for instance, Shapiro (2007) or Greenwald and Stiglitz (2014a, 2014b, 2014c).

9. In recent years, there has developed a broad critique of intellectual property within the economics literature. See, e.g. Bessen ((2008), Boldrin and Levine (2013), and Moser (2013).

10. There is, by now, a large literature not only questioning this standard wisdom, but supporting the theses which we have articulated in the previous paragraph. See, for instance, Boldrin and Levine (2010), Boyle (2003), Granstrand (2005), Scotchmer (2004), Winter (1993) and the many other references in the bibliography of this introduction and Chapter 2 in this volume.

11. Nonetheless, in much of the discussion below we shall, for simplicity, follow the conventional practice of referring to "strong" or "tight" IPR regimes. Much of the discussion here and below borrows from Stiglitz (2013a).

12. This was one of the central messages of Stiglitz (2002). 
We would like to cial support of the d Scuola Superiore

enable intellectual rust of trade agreend services (and in flow of knowledge. trong advocates of sion of intellectual hagwati (2004). eral Assembly at the

eric were eventually Stiglitz, 2006 and 1ese costs. In United court, in arguing for rms desiring to stay uipped to engage in could be incalculable ider royalties which it of the competitive nd Perleman (2002). e reluctance of some io-diversity conven-

ated with intellectual Journal of Economic returns has become or Greenwald and ctual property within 1d Levine (2013), and standard wisdom, but us paragraph. See, for nd (2005), Scotchmer e bibliography of this simplicity, follow the regimes. Much of the
13. There is another mechanism by which patents may lead to more innovation, by facilitating a market for innovations, and thus making investments in innovation more liquid and stimulating the diffusion of knowledge. (See Arora, Fosfuri, and Gambardella, 2001 and Maskus, 2005, for detailed analyses). While it is certainly true that some IPR protection is often a necessary condition for the development of markets for technologies, there is no clear evidence that more protection means a better market for technology or that "better markets" mean more innovation. Rather, the degree to which technological diffusion occurs via market exchange depends to a great extent on the nature of technological knowledge itself, including its degree of codifiability.

14. For a brief discussion of the case, see Stiglitz (2013d).

15. Even this statement is not entirely accurate: optimal production and investmentif firms were able to define them-would then take into account the learning benefits, and thus production or investment would be greater than otherwise (provided the firm can appropriate for itself the learning benefits). See Arrow (1962b) and Greenwald and Stiglitz (2014a).

16. We will qualify this point later, showing that for some kinds of knowledge, firms are able to appropriate returns even without government action, i.e. without patents.

17. In the technical jargon, a public good faces a problem of excludability and nonrivalrous consumption (Samuelson, 1954). The notion of knowledge as a public good is discussed in Stiglitz (1987a), and the notion that knowledge is a global public good is discussed in Stiglitz $(1995,1999)$.

18. Jeremy Bentham $(1839$, p. 71$)$ put the argument for patents forcefully:

[T] hat which one man has invented, all the world can imitate. Without the assistance of the laws, the inventor would almost always be driven out of the market by his rival, who finding himself, without any expense, in possession of a discovery which has cost the inventor much time and expense, would be able to deprive him of all his deserved advantages, by selling at a lower price.

19. Some of the reasons for this are discussed below. One is that to obtain a patent, one is supposed to disclose information, information which itself might be valuable to rivals. Another is that in some sectors much relevant information is "tacit," not easily described in a patent application.

20. Stiglitz (2013c) shows that even if a stronger ("tighter") intellectual property regime resulted in a higher incentive to innovate, given the set of technological opportunities (the "knowledge pool"), a stronger intellectual property regime may result in a diminished technological pool, so that the overall level of innovation is diminished.

21. See for example the discussion in Henry and Stiglitz (2010). The far-reaching America Invents Act of 2011, which comes into force in March 2013, has significantly de-emphasized the need for disclosure in order to enforce patents. The law and related documents may be viewed at <http://judiciary.house.gov/ issues/issues_patentreformact2011.html > (accessed on 8 January 2013).

22. See, for instance, Shapiro, 2001.

23. This section relies heavily on Stiglitz, 2012.

24. See, for instance, Shapiro, 2010. 
25. In a perfectly functioning system, presumably there would be a deal between the patent holder and the new entrant that would avoid this wasteful expenditure, and make both parties better off. With imperfect information, the patent holder may not be able to tell who will be successful at circumventing his patent. He can't make such a deal with every possible claimant.

26. The smarthphone litigation between Samsung and Apple has exemplified the problems. See Graham and Vishnubhakat, 2013.

27. This is not true of some of the more recent theoretical work, including that focusing on weak patents, holdups and so on: $\mathrm{cf}$. also the references above.

28. That is why holdups can have such an adverse effect on innovation: even a small "innovation" that is part of a new product, like a microprocessor, can extract a disproportionate share of the rents associated with the entire microprocessor.

29. See, e.g. the large literature on learning by doing, including Greenwald and Stiglitz (2014a), Stiglitz (2013b), Arrow (1962b), Pavitt (1987), Dosi and Nelson (2010) and the references cited there.

30. The suit The Association for Molecular Pathology et al. v. United States Patent and Trademark Office et al. provides an example of this variability. In June 2013, the Supreme Court ruled in a landmark decision that human genes could not be patented, after many contradictory rulings in lower courts, some of which had upheld Myriad Genetics' patents on a pair of genes linked to breast and ovarian cancer. See Stiglitz (2013d) for a more complete discussion. See also Harhoff, Regibeau, and Rockett (2001). For a more extensive discussion of the "law and economics" of intellectual property, see Stiglitz (2008); Maskus and Reichman (2004); Lewis and Reichman (2005); and Merges and Nelson (1994).

31. See, for instance, Dasgupta and David (1994).

32. For instance, because of increased incentives for secrecy, undermining the openness that has traditionally characterized academic settings.

33. See Farrell and Shapiro (2008).

34. In the concluding section of this paper, we note some changes in the US that may have reduced the adverse consequences of IPR.

35. In that Bayh-Dole was thus a major departure from the conception advanced by the Robert Merton (1973) of the "republic of science."

36. Though to the extent that universities share some of the royalties with researchers, the potential gain in their income may result in universities being able to recruit researchers at a lower wage than they otherwise could. We have seen no convincing evidence that this is the case.

37. For a more extensive discussion of the new regulations, see Coriat, Orsi, and Weinstein (2003). Discussion of the 1984 regulation change can be found at $<$ http://finra.complinet.com/en/display/display_main.html?rbid=2403\&element_ id $=754$ \&print $=1>$ (accessed 4 April 2013).

38. Obviously, if there were no way of appropriating returns other than patent protection, then in such a world there would be little innovation. Everyone would be a free rider. But we have emphasized that a model in which it is assumed that knowledge disseminates perfectly in the absence of patents is wrong-and so even in the absence of patent protection there will be innovation. The question is whether strengthening patent rights will increase the overall pace of innovation

from this bas stronger intell

39. Defenders of opportunities would have fa seem to sugg system itself 1 opportunities.

40. The adverse mentioned $a b$

41. That is to say sectors acquir little innovatic acquisition of

42. The emerging Teece, Pisano (2007); amon Marengo, 200 their distinct things"--searc porations deri small number rically, laggard tion technolos routines and c barriers to lea organization $\mathrm{g}$ (more on all th and Nelson, 2 among firms is

43. As we have alr prices resulting (including tho are constraine

44. An archetypic would have occ been discovere

45. This section $\mathrm{dr}$

46. The governmer system besides agriculture, its ation of knowl roles in manuf could, and sho 2009, 2010 an 


\section{Intellectual Property Rights in the Development Process}

eal between the xpenditure and ent holder may atent. He can't

exemplified the including that ces above.

on: even a small r, can extract a roprocessor. wald and Stiglitz Nelson (2010)

tates Patent and June 2013, the es could not be le of which had ast and ovarian e also Harhoff, of the "law and and Reichman 94).

lining the open-

the US that may

ion advanced by

with researchers, g able to recruit seen no convin-

oriat, Orsi, and an be found at 2403\&element

her than patent ation. Everyone ich it is assumed wrong-and so The question is ce of innovation from this base level, given the adverse effects that we have noted. Advocates of stronger intellectual property rights have never demonstrated that this is the case.

39. Defenders of IPR would, of course, claim that this is not a good test: technological opportunities may have been diminished, and in the absence of strong IPR, NCE would have fallen even more. But the remarkable advances in basic science would seem to suggest a rapid expansion of technological opportunities. The patent system itself may be part of the explanation of the diminution in technological opportunities. See Stiglitz $2013 c$.

40. The adverse effects of patents on genes were noted in the Myriad litigation mentioned above. See Huang and Murray, 2008, and Williams, 2013.

41. That is to say via capital and intermediate inputs embodied innovation that some sectors acquire from others. So, for example, the textile industry undertakes very little innovation of its own but undergoes a good deal of technical progress via the acquisition of new machinery and new fibers introduced elsewhere in the system.

42. The emerging capability-based theory of the firm (cf. Nelson and Winter, 1982; Teece, Pisano and Shuen, 1997; Dosi, Nelson and Winter, 2000, and Helfat et al. (2007); among many distinguished others, and the survey in Dosi, Faillo and Marengo, 2008) identifies a fundamental source of differentiation across firms in their distinct problem-solving knowledge, yielding different abilities of "doing things"-searching, developing new products, manufacturing, etc. Successful corporations derive competitive strength from their above-average performance in a small number of capability clusters where they can sustain leadership. Symmetrically, laggard firms often find it hard to imitate perceived best-practice production technologies because of the difficulty of identifying the combination of routines and organizational traits that makes company $x$ good at doing $z$. Such barriers to learning and imitation relate to collective practices which in every organization guide innovative search, production and other corporate activities (more on all that in Chapter 16 of this book by Burlamaqui and Cimoli, and Dosi and Nelson, 2010. See also Greenwald and Stiglitz, 2014a). A critical difference among firms is thus their capabilities in learning (see Stiglitz, 1987b).

43. As we have already noted, in the context of developing countries, increased drug prices resulting from reduced access to generics means that other social objectives (including those associated with health) and spending on development projects are constrained. It is not just a matter of consumption.

44. An archetypical case to the point is the Myriad gene patent: the "innovation" would have occurred even had Myriad not done its research-the gene would have been discovered just a little later as part of the IPR-free Human Genome Project.

45. This section draws upon Stiglitz (2013a).

46. The government could (and does) undertake other roles in a country's innovation system besides funding (and in some cases, undertaking) basic research. In agriculture, its extension services have played an important role in the dissemination of knowledge, and some have proposed that government undertake similar roles in manufacturing. In pharmaceuticals, it has been argued that government could, and should, take a more active role in testing. (See Jayadev and Stiglitz, 2009, 2010 and the Conclusion to this volume). Moreover, in most countries 
governments implicitly or explicitly undertake various arrays of industrial policies which deeply influence the rates and directions of innovative activities (more in Cimoli, Dosi, and Stiglitz, 2009).

47. And some of the so-called research money is really money spent on marketing: the manner in which drugs are tested is not necessarily designed to minimize cost, but to enhance drug sales after the drug is approved.

48. There are other ways by which innovation can be spurred in this instance. Just like the granting of patent can be viewed as a prize, but an inefficient one, so too can the guarantee purchase fund advocated by some for promoting innovation for medicines for diseases endemic to developing countries be viewed as a prize. In this approach, the World Bank or the Gates Foundation would guarantee one or two billion dollars to the person or people who develop a vaccine or cure for AIDS, malaria, or some other disease afflicting the developing world for the purchase of the drug. In effect, there would be a certain market. A sufficiently large guarantee would provide a clear motivation for research. These guaranteed purchase funds, however, would still maintain the inefficiency of the monopoly patent system, unless there was an accompanying commitment that would make the patent accessible to all at reasonable royalties for purchases beyond the guarantee. With the guarantee fund the discoverer still receives his "prize"-the monopoly profits-by charging monopoly prices. The poor, who get the drugs through the guaranteed purchase fund do not, of course, pay the monopoly price. But the funds are limited and when they are used up, without such a commitment, a government that wants to provide to its citizens, say, the malaria medicine that has been bought through the guarantee purchase fund, will have to pay the full monopoly price. Money spent purchasing this drug at the monopoly price is money that cannot be spent on the country's other health needs. It may be far better to use the money for the guarantee purchase fund in a way which spurs competition in the provision of the drug, to offer a prize, or to buy the patent, and to allow anyone willing to pay a limited licensing fee to produce it.

49. There may be less to this distinction than meets the eye. Within companies, there is a research board that has to approve projects, allocating funds among alternatives. Even individual entrepreneurs seeking funds for research turn to a bank, and any large project will have to be vetted by the bank. In short, research funds are never allocated by an auction mechanism; there is almost always some review board. In our diverse society, any project may be reviewed by multiple boardsthere are multiple foundations to which a university research can turn, and an entrepreneur can turn to multiple corporations. Thus, in practice, decisionmaking involves a mixture of hierarchical (committee) and polyarchical decisionmaking structures. (See Sah and Stiglitz, 1985, 1986, 1988). A key distinction, however, is who bears the losses and who reaps the gains.

50. This seems to be one of the arguments that Mill used in favor of patents, arguing that it avoided "discretion." See John Stuart Mill (1862), as cited in Mennell (1999).

51. See the observation made earlier comparing expenditures on lawyers and on research.

52. The evid because Stiglitz ( ior and a in a risl markets even whe

53. They are research effective holdup i market d demand

54. Data fro1 profile o profile/c

55. In fact, $t$ non-mor data) wit capita in Many lo them it knowled are more many ar

56. For a fu discussio

57. eBay Inc found at on 15 Ja1

58. Stiglitz ( declaring Compon Trade C

Angell, M. (2 What to $D$ Arora, A., A. Innovation Arrow K. (19 in R. Nels Princeton 
industrial policies ctivities (more in

on marketing: the ninimize cost, but

instance. Just like it one, so too can ig innovation for ved as a prize. In guarantee one or or cure for AIDS, $r$ the purchase of $y$ large guarantee 1 purchase funds, ly patent system, make the patent d the guarantee. --the monopoly rugs through the ly price. But the commitment, a medicine that has to pay the full onopoly price is ds. It may be far way which spurs $y$ the patent, and it.

companies, there ; among alternann to a bank, and search funds are ays some review ultiple boards1 can turn, and actice, decisionrchical decisionkey distinction,

patents, arguing ited in Mennell

lawyers and on
52. The evidence is that capital markets do not fully spread risks faced by firms, because of massively imperfect information. See for example Greenwald and Stiglitz (1990) who discuss the effect of information imperfections on firm behavior and argue that informational problems in the capital market cause firms to act in a risk-averse manner. There is also considerable empirical evidence that markets do not efficiently distribute risk, i.e., firms act in a risk-averse manner, even when risks are uncorrelated with the market. See, e.g., Stiglitz, 1982.

53. They are distorted, as we have noted, because there are incentives to engage in research to innovate around a patent and to spend money in ways that extend the effective life of the patent. They are distorted too by the incentives provided for holdup innovations. These innovation distortions are in addition to the other market distortions, such as those associated with expenditures attempting to make demand curves less elastic.

54. Data from the World Intellectual Property Organizations online statistical country profile of China, available at <http://www.wipo.int/ipstats/en/statistics/country_ profile/countries/cn.html> (accessed 14 January 2013).

55. In fact, the relationship between observed IPR regimes and income seems to be non-monotonic (though one should not make inferences about causality from the data) with a $U$-shaped relationship between the tightness of IPR regimes and per capita incomes (Maskus, 2000; Murmann, 2003; and Chapter 2 in this volume). Many low-income countries seem to have high levels of IPR-perhaps because for them it doesn't matter as they don't even have the capabilities of borrowing knowledge from others. (Alternatively, it may be because these poorer countries are more subject to pressure from the advanced industrial countries, e.g. because many are very aid dependent and are dependent on discretionary trade benefits.)

56. For a further critique of TRIPS, see Charlton and Stiglitz, 2005. For a broader discussion, see UNCTAD-ICTSD (2005).

57. eBay Inc. v. MercExchange, L.L.C., 547 U.S. 388 (2006), case documents can be found at <http://www.supremecourt.gov/opinions/05pdf/05-130.pdf> (accessed on 15 January 2013).

58. Stiglitz (2012). The ITC eventually ruled in favor of Intel in February, 2013, by declaring the patents either invalid or not infringed. Matter of Microprocessors, Components Thereof, and Products Containing Same, 337-781, U.S. International Trade Commission.

\section{REFERENCES}

Angell, M. (2004), The Truth about the Drug Companies: How They Deceive Us and What to Do about It. New York: Random House.

Arora, A., A. Fosfuri and A. Gambardella (2001), Markets for Technology: Economics of Innovation and Corporate Strategy. Cambridge, MA: MIT Press.

Arrow K. (1962a), "Economic Welfare and the Allocation of Resources for Invention," in R. Nelson, ed., The Rate and Direction of Inventive Activity. Princeton, NJ: Princeton University Press. 
- (1962b), "The Economic Implications of Learning by Doing," Review of Economic Studies 29: 155-73.

Association for Molecular Pathology v. Myriad Genetics, 569 U.S. 12-398 [2013].

Avorn, J. (2004), Powerful Medicines: The Benefits, Risks, and Costs of Prescription Drugs. New York: Knopf.

Barton J. (2000), "Reforming the Patent System," Science, 287: 1933-4.

Bentham, Jeremy (1839), A Manual of Political Economy. New York: G.P. Putnam.

Bessen, James, and Michael J. Meurer (2008), Patent Failure: How Judges, Bureaucrats, and Lawyers Put Innovators at Risk. Princeton, NJ: Princeton University Press.

Bessen J. and E. Maskin (2000), "Sequential Innovation, Patents and Imitation," Working Paper 00-01, MIT Department of Economics, Cambridge, MA, available at <http://www.ftc.gov/os/comments/intelpropertycomments/jimbessenericmaskin. pdf $>$ (accessed 14 January 2013).

-(2004), In Defense of Globalization. New York: Oxford University Press.

Boldrin M. and D.K. Levine (2008), "Perfectly Competitive Innovation," Joumal of Monetary Economics, 55 (3): 435-53.

- (2010), Against Intellectual Monopoly. Cambridge: Cambridge University Press.

Boldrin, Michele, and David K. Levine (2013), "The Case against Patents," Journal of Economic Perspectives, 27 (1): 3-22.

Boyle, J. (2003), "The Second Enclosure Movement and the Construction of the Public Domain," Law and Contemporary Problems, 66 (33): 33-74.

Bradshaw, G.F. (1992), "The Airplane and the Logic of Invention," in R.N. Giere, ed., Cognitive Models of Science. Minneapolis, MN: University of Minnesota Press.

Brand, R. (2005), "The Basmati Patent," in E.U. von Weizäcker, O.R. Young, and M. Finger, eds, Limits to Privatization: How to Avoid Too Much of a Good Thing. London: Earthscan Publications.

Chang, H.J. (2002), Kicking Away the Ladder-Development Strategy in Historical Perspective. London: Anthem Press.

Charlton, A. and J.E. Stiglitz (2005), Fair Trade for All. New York: Oxford University Press.

Cimoli M., G. Dosi, and J.E. Stiglitz (eds) (2009), Industrial Policy and Development: The Political Economy of Capabilities Accumulation. New York: Oxford University Press.

Cohen W.M. and D.A. Levinthal (1990), "Absorptive Capacity: A New Perspective on Learning and Innovation," Administrative Science Quarterly, Special 1ssue: Technology, Organizations, and Innovation, 35 (1): 128-52.

Cohen W., R.R. Nelson, and J. Walsh (2000), "Protecting Their Intellectual Assets: Appropriability Conditions and Why US Manufacturing Firms Patent or Not," Discussion Paper 7552, NBER.

Coriat, B. and F. Orsi (2006), "The New Role and Status of Intellectual Property Rights in Contemporary Capitalism," Competition and Change, 10 (2): 162-79.

- and C. d'Almeida (2006), "TRIPS and the International Public Health Controversies: Issues and Challenges," Industrial and Corporate Change, 15 (6): 1033-62.

- and O. Weinstein (2003), "Does Biotech Reflect a New Science-Based Innovation Regime?" Industry and Innovation, 10 (3): 231-53.
Dasgupta, P. Policy, 23 and J.E. Bell Journo

- 198

European

David, P.A. tents, $\mathrm{Cop}$ M.B. Wall lectual Pro

(2002),

Informatio sented at $\mathrm{C}$ $\checkmark(2004 a)$, Science," i (CODE). C (2004b), alist Econ 571-89.

Dosi G. A Suggeste Change," $F$ (1988), “ of Econom M. Faillo ledge Accu tion," Orga - P. Lleren Technologi Myths and (10): 1450 L. Maren Innovators Innovation - and R.R. tionary Pro of Innovati _R. Nelsor tional Capo

Farrell, J. an Economic

Fink C. and $\mathrm{K}$ and New Y Freeman, C. Japan. Lon 
w of Economic

98 [2013].

of Prescription

J.P. Putnam.

S, Bureaucrats, rsity Press.

nd Imitation," MA, available senericmaskin.

Press.

ion," Journal of

aiversity Press. ents," Journal of

Ion of the Public

R.N. Giere, ed., lesota Press.

.R. Young, and of a Good Thing.

egy in Historical

xford University ind Development: xford University

ew Perspective on ecial Issue: Tech-

ntellectual Assets: s Patent or Not,"

al Property Rights 162-79.

ublic Health ConChange, 15 (6):

ence-Based Innov-
Dasgupta, P. and P.A. David (1994), "Toward a New Economics of Science," Research Policy, 23 (5): 487-521.

and J.E. Stiglitz (1980), "Uncertainty, Market Structure and the Speed of R\&D," Bell Journal of Economics, 11 (1): 1-28.

- (1988), "Potential Competition, Actual Competition and Economic Welfare," European Economic Review, 32: 569-77.

David, P.A. (1993), "Intellectual Property Institutions and the Panda's Thumb: Patents, Copyrights, and Trade Secrets in Economic Theory and History," in M.B. Wallerstein, M.E. Mogee, and R.A. Schoen, eds, Global Dimensions of Intellectual Property Rights in Science. Washington, DC: National Academies Press.

(2002), "Does the New Economy Need All the Old IPR Institutions? Digital Information Goods and Access to Knowledge for Economic Development," Presented at Wider Conference on the New Economy in Development, Helsinki, 2002. - (2004a), "From Keeping Nature's Secrets to the Institutionalization of Open Science," in R.A. Ghosh, ed., Collaborative Ownership and the Digital Economy (CODE). Cambridge, MA: MIT Press.

(2004b), "Understanding the Emergence of "Open Science' Institutions: Functionalist Economics in Historical Context," Industrial and Corporate Change, 13: $571-89$.

Dosi; G. (1982), "Technological Paradigms and Technological Trajectories: A Suggested Interpretation of the Determinants and Direction of Technological Change," Reaserch Policy, 11: 147-62.

(1988), "Sources, Procedures, and Microeconomic Effects of Innovation," Journal of Economic Literature, 26 (3): 1120-71.

M. Faillo and L. Marengo (2008), "Organizational Capabilities, Patterns of Knowledge Accumulation and Governance Structures in Business Firms: An Introduction," Organization Studies, 29 (8): 1165-85.

-. P. Llerena and M. Sylos Labini (2006), "The Relationships between Science, Technologies and Their Industrial Exploitation: An Illustration Through the Myths and Realities of the So-Called 'European Paradox', Research Policy, 35 (10): 1450-64.

- L. Marengo and C. Pasquali (2006), "How Much Should Society Fuel the Greed of Innovators? On the Relations Between Appropriability, Opportunities and Rates of Innovation," Research Policy, 35 (8): 1110-21.

1. and RR. Nelson (2010), "Technical Change and Industrial Dynamics as Evolutionary Processes," in B.H. Hall and N. Rosenberg, eds, Handbook of the Economics of Innovation, vol. I. Burlington, MA: Academic Press.

R. Nelson, and S. Winter (eds) (2000). The Nature and Dynamics of Organizational Capabilities. Oxford and New York: Oxford University Press.

Farrell, J. and Carl Shapiro (2008), "How Strong Are Weak Patents?" American Economic Review, 98 (4): 1347-69.

Fink C, and K.E. Maskus (eds) (2005), Intellectual Property and Development, Oxford and New York: Oxford University Press.

Freeman, C. (1987), Technology, Policy, and Economic Performance: Lessons from Japan London and New York: Pinter Publishers. 
— and L. Soete (1997), The Economics of Industrial Innovation, 3rd edn. London: Pinter.

Fudenberg, D., R. Gilbert, J.E. Stiglitz and J. Tirole (1983), "Preemption, Leapfrogging and Competition in Patent Races," European Economic Review, 22: 3-32.

Gallini N. (2002), "The Economics of Patents: Lessons from Recent U.S. Patent Reform," Joumal of Economic Perspectives, 16: 131-54.

Gambardella, A. (1995), Science and Innovation: The US Pharmaceutical Industry in the 1980's. Cambridge: Cambridge University Press.

Gilbert, R.J. and D.G.M. Newbery (1982), "Preemptive Patenting and the Persistence of Monopoly," American Economic Review, 72 (3): 514-26.

Graham, S., and S. Vishnubhakat (2013), "Of Smart Phone Wars and Software Patents," Journal of Economic Perspectives, 27 (1): 67-86.

Granstrand O. (2005), "Innovation and Intellectual Property Rights," in I. Fagerberg, D. Mowery and R. Nelson, eds, The Oxford Handbook of Innovation. Oxford: Oxford Uniyersity Press.

Greenwald, B. and J.E. Stiglitz (1990), "Asymmetric Information and the New Theory of the Firm: Financial Constraints and Risk Behavior," American Economic Review, $80(2): 160-5$.

— (2014a), Creating a Learning Society: A New Approach to Growth, Development, and Social Progress, Inaugural Arrow Lecture, Columbia University. New York: Columbia University Press.

(2014b), "Industrial Policies, the Creation of a Learning Society, and Economic Development," in J.E .Stiglitz and J.Y. Lin, eds, The Industrial Policy Revolution I: The Role of Government Beyond Ideology. Houndmills, UK and New York: Palgrave Macmillan.

___ (2014c), "Learning and Industrial Policy: Implications for Africa," in J.E. Stiglitz, J.Y. Lin, and E. Patel, eds, The Industrial Policy Revolution II: Africa in the $21^{\text {st }}$ Century, Houndmills, UK and New York: Palgrave Macmillan.

Hagiu, A., and D. B. Yoffie (2013), "The New Patent Intermediaries: Platforms, Defensive Aggregators, and Super-Aggregators," Journal of Economic Perspectives, 27 (1): 45-66.

Hall, B. (2005), "Exploring the Patent Explosion," Journal of Technology Transfer, 30: $35-48$.

- and R. Ziedonis (2001), “The Patent Paradox Revisited: Firm Strategy and Patenting in the US Semiconductor Industry," Rand Journal of Economics, 32: 101-28

Harhoff, D.P., P. Regibeau and K. Rockett (2001), "Some Simple Economics of GM Food," Economic Policy, 16 (33): 263-99.

Helfat C., S. Finkelstein, W. Mitchell, M. Peteraf, H. Singh, D. Teece and S. Winter (eds) (2007), Dynamic Capabilities: Understanding Strategic Change in Organizations. Malden/Oxford: Blackwell Publishing.

Heller M. (1998), "The Tragedy of the Anticommons: Property in Transition from Marx to Markets," Harvard Law Review, 111: 698-701.

—- and R. Eisenberg (1998): "Can Patents Deter Innovation? The Anti-commons in Biomedical Research," Science, 280: 698-701.
Henry, C. and Sust

Hertel, G., An Inte $32(7): 1$

Huang, $\mathrm{K}$. Supply Manage

Jaffe A. (2 Innovati and $\mathrm{J}$. Univers Jayadev, A Pharma

Socially Generic

Kennedy, teristics.

Klevorick, industry

Kortum S. What Is Public P

Landes D.

Lerner J. ( and Pro $-(2010)$ $28-37$.

and J Industri - and $\mathrm{S}$

Chicago

Levin, R., from In

Lewis, T. a in Devel J. Reich Globaliz

Love, J. (2 Medical United Series N en/publ non-vol $p d f>(a$ 
3rd edn. London:

tion, Leapfrogging 22: $3-32$.

Recent U.S. Patent

ceutical Industry in

and the Persistence

Nars and Software

1ts," in I. Fagerberg, Innovation. Oxford:

and the New Theory in Economic Review,

to Growth, Developbia University. New

ng Society, and Ecodustrial Policy Revo, UK and New York;

ns for Africa," in J.evolution II: Africa in Iacmillan.

mediaries: Platforms, conomic Perspectives,

chnology Transfer, 30:

d: Firm Strategy and nal of Economics, 32:

ple Economics of GM

. Teece and S. Winter c Change in Organizarty in Transition from The Anti-commons in
Henry, C. and J.E. Stiglitz (2010), "Intellectual Property, Dissemination of Innovation and Sustainable Development," Global Policy, 1: 237-51.

Hertel, G., M. Krishnan and S. Slaughter (2003), "Motivation in Open Source Projects: An Internet-based Survey of Contributors to the Linux Kernel," Research Policy, 32 (7): $1159-77$.

Huang, K.G. and F.E. Murray (2008), "Does Patent Strategy Shape the Long-Run Supply of Public Knowledge? Evidence from Human Genetics," Academy of Management Journal, 52 (6): 1193-221.

Jaffe A. (2000): "The US Patent System in Transition: Policy Innovation and the Innovation Process," Research Policy, 29: 531-57.

-and J. Lerner (2004): Innovation and its Discontents. Princeton, NJ: Princeton University Press.

Jayadev, A. and Stiglitz, J.E. (2009), "Two Ideas to Increase Innovation and Reduce Pharmaceutical Costs and Prices," Health Affairs, 28 (1): 165-8.

(2010), "Medicine for Tomorrow: Some Alternative Proposals to Promote Socially Beneficial Research and Development in Pharmaceuticals," Journal of Generic Medicines, 7 (3): 217-26.

Kennedy, D. and J.E. Stiglitz (eds) (2013), Law and Economics with Chinese Characteristics. Oxford and New York: Oxford University Press.

Klevorick, A., R. Levin, R. Nelson and S. Winter (1995), "On the Sources and Interindustry Differences in Technological Opportunities," Research Policy, 24: 185-205.

Kortum S., and J. Lerner (1998), "Stronger Protection or Technological Revolution: What Is Behind the Recent Surge in Patenting?" Rochester Conference Series on Public Policy, 48: 247-307.

Landes D. (1969), The Unbound Prometheus. Cambridge: Cambridge University Press. Lerner J. (2002), "150 Years of Patent Protection," American Economic Review Papers and Proceedings, 92: 221-5.

- (2010), "The Patent System in a Time of Turmoil," The WIPO Journal, 2 (1): 28-37.

and J. Tirole (2002), "Some Simple Economics of Open Source," Journal of Industrial Economics, 52 (2): 197-234.

and S. Stern (eds) (2012), The Rate and Direction of Inventive Activity Revisited. Chicago: NBER/University of Chicago Press.

Levin, R., A. Klevorick, R.R. Nelson and S. Winter (1987), "Appropriating the Returns from Industrial R\&D," Brookings Papers on Economic Activity, 1987 (3): 783-831.

Lewis, T. and Reichman, J. (2005), "Using Liability Rules to Stimulate Local Innovation in Developing Countries: Application to Traditional Knowledge," in K. Maskus and J. Reichman, eds, International Public Goods and Transfer of Technology under a Globalized Intellectual Property Regime. Cambridge: Cambridge University Press.

Love, J. (2005), "Remuneration Guidelines for Non-Voluntary Use of a Patent on Medical Technologies," working paper of the World Health Organization and United Nations Development Programme, Health Economics and Drugs TCM Series No. 18, available at <http:/www.undp.org/content/dam/aplaws/publication/ en/publications/poverty-reduction/poverty-website/renumeration-guidelines-fornon-voluntary-use-of-a-patent-on-medical-techologies-/RenumerationGuidelines. pdf> (accessed 15 January 2013). 
Lundvall, B.-A. (ed.) (2010), National Systems of Innovation: Toward a Theory of Innovation and Interactive Learning. London: Anthem Press.

Machiup, F. (1958), "An Economic Review of the Patent System," Discussion paper, U.S. Congress, Washington D.C. Government Printing Office.

Maskus, K.E. (1997) "Should Core Labor Standards Be Imposed through International Trade Policy?" The World Bank Policy Research Working Paper Series, no. 1817.

- (2000), "Intellectual Property Rights and Economic Development," Case Western Reserve Journal of International Law, 32 (3): 471-506.

- (2005), "The Role of Intellectual Property Rights in Encouraging Foreign Direct Investment and Technology Transfer" in Fink and Maskus (2005).

_ the Privatization of Global Public Goods," Journal of International Economic Law, 7 (2): 279-320.

Mazzucato M. and G. Dosi (eds) (2006), Knowledge Accumulation and Industry Evolution. Cambridge: Cambridge University Press.

Meier, H.A. (1981), "Thomas Jefferson and a Democratic Technology," in C.W. Pursell, ed., Technology in America: A History of Individuals and Ideas, 2 nd edn. Cambridge, MA: MIT Press.

Mennell, P.S. (1999), "1600, Intellectual Property: General Theories," in Boudewijn Bouckaert and Gerrit De Geest, eds, Encyclopedia of Law and Economics, available online only at <http://encyclo.findlaw.com/index.html> (accessed 5 April 2013),

Merges R. (1996), "Contracting into Liability Rules: Intellectual Property Rights and Collective Rights Organizations," California Law Reviews, 84: 1293-386.

_ and R. Nelson (1994), "On Limiting or Encouraging Rivalry in Technical Progress: The Effects of Patent Scope Decisions," Journal of Economic Behavior and Organization, 25: 1-24.

Merton R. (1973), The Sociology of Science: Theoretical and Empirical Investigations. Chicago: University of Chicago Press.

Mill, John Stuart (1862), Principles of Political Economy, 5th edn; first published 1848. New York: Appleton.

Moser P. (2005), "How Do Patent Laws Influence Innovation? Evidence from Nineteenth-century World Fairs," The American Economic Review 95 (4): 1214-36.

Moser, Petra (2013), "Patents and Innovation: Evidence from Economic History," Journal of Economic Perspectives, 27 (1): 23-44.

Mowery D., R. Nelson, B. Sampat and A. Ziedonis (2001), "The Growth of Patenting and Licensing by US Universities: An Assessment of the Effects of the Bayh-Dole Act of 1980," Research Policy, 30 (1): 99-119.

Murmann, J.P. (2003), Knowledge and Competitive Advantage: The Coevolution of Firms, Technology, and National Institutions. Cambridge: Cambridge University Press.

Murray, F.E., P. Aghion, M. Dewatrepont, J. Kolev, and S. Stern (2011), "Of Mice and Academics," MIT Sloan Working Paper.

Nelson, R.R. (1959), "The Simple Economics of Basic Scientific Research," Journal of Political Economy, 67 (3): 297-306.

- (1993), National Systems of Innovation: A Comparative Study. New York: Oxford University Press.
- $2004 \mathrm{a})$, Whe I $455-72$.

$=(2004 \mathrm{~b})$, "The

Up,' Oxford Der

2. $(2006)$, Refle

Looking Back an

- and S. Winter

MA. Belknap Pr

North, D.C. (1981)

Nuvolari, A (2004

Mre Oase of the $347-63$.

Odagiri, $\mathrm{H}, \mathrm{A} . \mathrm{Go}$ Rights, Developr and New York:

Orsenigo L, G. I Accumulation, Policy Issues," Industry Evolut

Ostrom, E, R. G Resources. Ann

Pavitt, K. (1984), Theory," Reseal (- (1987), "The (

Perleman, M. (200 tion of Creativi

Pollack, A. (2011) July 2011 , avail in - cancer-test- 1

Pollard; S. (1981) Oxford: Oxforc

PriceWaterhouse to Rise amid $\mathrm{G}$ com/en_US/us, pdf $>$ (accessed

Sah, R. and J.E. American Econ - (1986), chies," Americ - (1988), 98 (391): 451-

Samuelson, P.A. ics and Statisti Schumpeter, J.A. ( Scotchmer, S. (2O Shapiro, C. (2001 Standard Setti and the Econo 
d a Theory of

scussion paper,

h International ies, no. 1817.

"Case Western

Foreign Direct

edge Goods and Economic Law,

$n$ and Industry

"echnology," in and Ideas, 2nd

" in Boudewijn omics, available 5 April 2013).

erty Rights and $-386$.

Technical Proic Behavior and

al Investigations.

published 1848.

ence from Nine4): 1214-36. nomic History,"

wth of Patenting of the Bayh-Dole Coevolution of ridge University 1), "Of Mice and earch," Journal of Jew York: Oxford
- (2004a), "The Market Economy and the Scientific Commons," Research Policy, 33: $455-72$.

- (2004b), "The Challenge of Building an Effective Innovation System for CatchUp," Oxford Development Studies, 32 (3): 365-74.

- (2006), "Reflections on 'The Simple Economics of Basic Scientific Research': Looking Back and Looking Forward," Industrial and Corporate Change, 15: 903-17. - and S. Winter (1982), An Evolutionary Theory of Economic Change. Cambridge, MA: Belknap Press of Harvard University Press.

North, D.C. (1981), Structure and Change in Economic History. New York: Norton.

Nuvolari, A. (2004), "Collective Invention Driving the British Industrial Revolution: The Case of the Cornish 'Pumping Engine'," Cambridge Journal of Economics, 28: 347-63.

Odagiri, H., A. Goto, A. Sunami and R.R. Nelson (eds) (2010), Intellectual Property Rights, Development, and Catch Up: An International Comparative Study. Oxford and New York: Oxford University Press.

Orsenigo L., G. Dosi, and M. Mazzucato (2006), "The Dynamics of Knowledge Accumulation, Regulation, and Appropriability in the Pharma-Biotech Sector: Policy Issues," in M. Mazzucato and G. Dosi, eds, Knowledge Accumulation and Industry Evolution. Cambridge: Cambridge University Press.

Ostrom, E., R. Gardner, and J. Walker (1994), Rules, Games and Common-Pool Resources. Ann Arbor, MI: The University of Michigan Press,

Pavitt, K. (1984), "Sectoral Patterns of Innovation: Toward a Taxonomy and a Theory," Research Policy, 13: 343-73.

_. (1987), "The Objectives of Technology Policy," Science and Public Policy, 14: 182-8. Perleman, M. (2002), Steal this Idea: Intellectual Property and the Corporate Confiscation of Creativity. New York: Palgrave.

pollack, A. (2011), "Ruling Upholds Gene Patent in Cancer Test," New York Times, 30 Iuly 2011, available at <http:/www.nytimes.com/2011/07/30/business/gene-patentin-cancer-test-upheld-by-appeals-panel.html> (accessed 5 September 2013).

Pollard, S. (1981), Peaceful Conquest: The Industrialization of Europe, 1760-1970. Oxford: Oxford University Press.

PriceWaterhouse Coopers (2012), "2012 Patent Litigation Study: Litigation Continues to Rise amid Growing Awareness of Patent Value," available at <http://www.pwc. com/en_US/us/forensic-services/publications/assets/2012-patent-litigation-study. pdf $>$ (accessed 9 November 2012).

Sah, R. and J.E. Stiglitz (1985), "Human Fallibility and Economic Organization," American Economic Review, 75 (2): 292-6.

- (1986), "The Architecture of Economic Systems: Hierarchies and Polyarchies," American Economic Review, 76 (4): 716-27.

- (1988), "Committees, Hierarchies and Polyarchies," The Economic Journal, 98 (391): 451-70.

Samuelson, P.A. (1954), “The Pure Theory of Public Expenditure," Review of Economics and Statistics, 36 (4): 387-9.

Schumpeter, J.A. (1943), Capitalism, Socialism and Democracy. London: G. Allen \& Unwin. Scotchmer, S. (2004), Innovation and Incentives. Cambridge, MA: The MIT Press.

Shapiro, C. (2001), "Navigating the Patent Thicket; Cross Licenses, Patent Pools, and Standard Setting," in A. Jaffe, Josh Lerner and Scott Stern, eds, Innovation Policy and the Economy. Cambridge, MA: MIT Press. 
(2007), "Patent Reform: Aligning Reward and Contribution 33-35," Working Paper No. 13141, National Bureau of Economic Research, Cambridge, MA, available at $\langle$ http://papers.nber.org/papers/w13141> (accessed 5 September 2013),

-(2010), "Injunctions, Hold-Up, and Patent Royalties," American Law and Economics Review, 12 (2): 280-313.

Stiglitz, J. (1982), "Ownership, Control and Efficient Markets: Some Paradoxes in the Theory of Capital Markets," in K.D. Boyer and W.G. Shepherd, eds, Economic Regulation: Essays in Honor of James R. Nelson. East Lansing: Michigan State University Press.

— (1987a), "On the Microeconomics of Technical Progress," in J.M. Katz, ed., Technology Generation in Latin American Manufacturing Industries. London: Macmillan Press. (Presented to IDB-CEPAL Meetings, Buenos Aires, November 1978.)

- (1987b), "Learning to Learn, Localized Learning and Technological Progress," in

P. Dasgupta and P. Stoneman, eds, Economic Policy and Technological Performance. Cambridge: Cambridge University Press.

- (1988), "Technological Change, Sunk Costs and Competition," Brookings Papers on Economic Activity, 3: 883-947.

-(1994), Wither Socialism. Cambridge, MA: MIT Press.

- (1995), "The Theory of International Public Goods and the Architecture of International Organizations," Background Paper No. 7, Third Meeting, High Level Group on Development Strategy and Management of the Market Economy, UNU/WIDER, 8 July, Helsinki, Finland.

__ (1999), "Knowledge as a Global Public Good," in Inge Kaul, 1sabelle Grunberg and Marc A. Stern, eds, Global Public Goods: International Cooperation in the 21st Century, United Nations Development Programme. New York: Oxford University Press.

- (2002), Globalization and its Discontents. New York: W.W. Norton.

- (2004), "Towards a Pro-Development and Balanced Intellectual Property Regime," keynote address presented at the Ministerial Conference on Intellectual Property for Least Developed Countries, World Intellectual Property Organization (WIPO), Seoul, 25 October, available at <http://www2.gsb.columbia.edu/faculty/ jstiglitz/download/2004_TOWARDS_A_PRO_DEVELOPMENT.htm> (accessed 5 November 2012).

(2006), Making Globalization Work. New York: W.W. Norton.

- (2008), "The Economic Foundations of Intellectual Property," Sixth Annual Frey Lecture in Intellectual Property, Duke University, Durham, NC, Duke Law Journal, 57 (6): 1693-724.

- (2012), "Rebuttal Testimony of Dr. Joseph Stiglitz on Behalf of Respondents Responding to Direct Testimony of Dr. Stern," in the Matter of Certain Microprocessors, Components Thereof, and Products Containing Same, United States International Trade Commission, Investigation No. 337-TA-781.

_ (2013a), "Institutional Design for China's Innovation System: 1mplications for Intellectual Property Rights," in D. Kennedy and J.E. Stiglitz, eds, Law and Economic Development with Chinese Characteristics: Institutions for the 21st Century. New York and Oxford: Oxford University Press.

- (2013b), "Learning, Growth, and Development: A Lecture in Honor of Sir Partha Dasgupta," in (2011), C. Sepúlveda, A. Harrison and J.Y. Lin, eds., Development Challenges in a Postcrisis World: Annual World Bank Conference on
Development $E$ French as "Apl Sir Partha Das!


working paper, - $(2013 \mathrm{~d})$, "Ho July 17 , availab intellectual-pro

'Hoen, E., (2003) Seattle, Doha a to HIV Care is ANRS.

... (2005), "Euro and Access to I and d'Almeida

Teece, D. (1986): tion, Collabora

- G. Pisano, an ment," Strategic

Tírole, J.(2002): “ pistes de réflexi

UNCTAD-ICTSD Cambridge Uni

Weber, S. (2005), Press.

Williams, H.L. (20 the Human Ger

Winter S. (1982), Economics and (1993), "Pater (2002): “A Vie 2002.

World Intellectual cators 2012," av cations/en/intpr Ziedonis R.H. (200 the Patent Acqu 
3-35," Working idge, MA, availnber 2013),

$n$ Law and Eco-

Paradoxes in the 1, eds, Economic Michigan State

J.M. Katz, ed, . London: MacJovember 1978.) ical Progress," in cal Performance.

Brookings Papers

Architecture of Meeting, High larket Economy,

lle Grunberg and the 21st Century, ersity Press.

ton.

lectual Property e on Intellectual rty Organization nbia.edu/faculty/ atm> (accessed

ixth Annual Frey uke Law Journal.

of Respondents ertain Microproiited States Inter-

Implications for aw and Economic st Century. New

n Honor of Sir in, eds., DevelopConference on
Development Economics. Washington, DC: The World Bank, pp. 37-88. Published in French as "Apprentissage, croissance et développement: conférence en l'honneur de Sir Partha Dasgupta," Revue d'Économie du Développment, 4: 19-86.

$-(2013 \mathrm{c})$, "Intellectual Property Rights, the Pool of Knowledge, and Innovation," working paper, Columbia University

(2013d), "How Intellectual Property Reinforces Inequality," The New York Times, July 17, available online at <http:/opinionator.blogs,nytimes.com/2013/07/14/howintellectual-property-reinforces-inequality/> (accessed 26 September 2013).

t'Hoen, E, (2003), "TRIPS, Pharmaceutical Patents and Access to Essential Medicines: Seattle, Doha and Beyond," in J.P. Moatti et al., eds, Economics of AIDS and Access to HIV Care in Developing Countries: Issues and Challenges. Paris: Editions de l' ANRS.

(2005), "European Union Committee on International Trade: Hearings on TRIPS and Access to Medicines," Tuesday 18 January, Strassburg. As cited in Coriat, Orsi and d'Almeida (2006).

Teece, D. (1986): "Profiting from Technological Innovation: Implications for Integration, Collaboration, Licensing and Public Policy," Research Policy, 15: 285-305.

- G. Pisano, and A. Shuen (1997): "Dynamic Capabilities and Strategic Management," Strategic Management Journal, 18: 509-33.

Tirole, J. (2002): "Protection de la propriété intellectuelle: une introduction et quelques pistes de réflexion," discussion paper, Conseil d'Analyse Economique, Paris.

UNCTAD-ICTSD (2005), Resource Book on TRIPS and Development. Cambridge: Cambridge University Press.

Weber, S. (2005), The Success of Open Source. Cambridge, MA: Harvard University Press.

Williams, H.L. (2013), "Intellectual Property Rights and Innovation: Evidence from the Human Genome," Journal of Political Economy, 121 (1): 1-27.

Winter S. (1982), "An Essay on the Theory of Production," in H. Hymans, ed., Economics and the World around It. Ann Arbor, MI: University of Michigan Press.

-(1993), "Patents and Welfare," Industrial and Corporate Change, 2 (2); 211-31.

_-(2002): "A View of the Patent Paradox," slides from a presentation at LBS, 20 May 2002.

World Intellectual Property Organization (2012), "World Intellectual Property Indicators 2012," available online at <http:/www.wipo.int/export/sites/www/freepublications/en/intproperty/941/wipo_pub_941_2012.pdf> (accessed 15 January 2013).

Ziedonis R.H. (2004): "Don't Fence Me In: Fragmented Markets for Technology and the Patent Acquisition Strategies of Firms," Management Science, 50 (6): 804-20. 